\title{
THE EFFECT OF SOME MOSAIC DISEASES ON CELL STRUCTURE AND ON THE CHLOROPLASTS
}

\author{
Melville T. CoOK
}

The early studies on the mosaic diseases of plants brought out two points which have been accepted very generally by most of the workers who have studied the histology and cytology of these diseases. They are: (1) the modifications of the cell structure of the leaf and (2) the modifications of the chloroplasts. Attention was called to the modification of the cell structure by Beijerinck in 1899, by Woods 1900 and 1902, by Iwanowski in 1.903 and by many others since that time. In 1899 Beijerinck expressed the opinion that mosaic of tobaceo was a disease of the chlorophyll bodies and finally became a disease of the plastic contents of the cells. In 1899-1900 König stated that the chloropla'sts were disorganized and the cell walls disappearing. Unfortunately this idea was quickly followed by the very widespread belief that the chlorosis or mosais diseases were due to the disintegration of the chloroplasts and this opinion is very generally reflected in the literature of the past thirty years. However, the fact that the chlorotic areas of many diseased plants gradually become green with age and exposure to sunlight tends to throw doubt on the theory of disintegration of the chloroplasts. Furthermore, it is very evident that this theory could not be applied to all types of virus disease of plants.

The author of this paper has made a study of these two phases of the subject and is of the opinion that the active agent in the mosaic diseases recorded in this paper is inhibitory in both cases. In the first case the cells of the chlorotic areas are inhibited so that there is a reduced growth with little or no differentiation of cell and tissue structures. In the second case the chloroplasts of the chlorotic areas are small and few in number as a result of the inhibitory action of the disease, but these areas tend to develop the normal green color with age.

This paper will be devoted to a review of the literature and to the results of the author's studies on these two points. However, it should be remembered that these studies do not include a study of the lesions which frequently occur in connection with virus diseases of plants. 


\section{CELL STRUCTURE}

Mayer (27) published the first important paper on a mosaic disease of a plant in 1886 but he did not record any histological studies. Iwanowski (19) says that Mayer made microscopic examinations of the juices only.

In 1899 Beijerinck (3) published the results of his studies in which he made two important statements: (1) that the green areas were diseased and the chlorotic areas normal, and (2) that the dividing or meristematic cells only could contract the disease. The first statement is incorrect because we now know that the active agent exists in both green and chlorotic areas and because later studies show that the chlorosis is the most conspicuous symptom of the disease. The second statement is more nearly correct because recent researches have shown that the histological modifications occur only when the active agent comes in contact with the meristematic cells before the tissues are fully differentiated.

In 1899 and 1900 Köning (23) and (24) published the results of histological studies on mosaic tobaceo leaves including drawings of cross sections but did not report anything of importance. His statement that intercellular cavities occurred among both the palisade and mesophyil cells leads one to suspect that his studies did not include the very young leaves.

In the year 1900, Heintzel (17) published a paper on tobacco mosaic in which he called attention to the greater prominence of intercellular spaces in the dark green, bloated areas than in the light green areas and expressed the opinion that these spaces were filled with gas. Later studies have shown that the intercellular spaces or the dark green areas are normal, or nearly normal, and that the reduced intercellular spaces in chlorotic areas are abnormal. Therefore, we are inclined to believe that Heintzel was influenced by Beijerinck's idea which was prevalent for a time, that the dark green areas were abnormal and the cholorotic areas normal.

In this same year Woods (35) published a paper on tobacco mosaic which gives the first clear statement that has come to our attention concerning the histological character of the chlorotic areas as compared with the tissues from normally green plants. He says:

"A study of the histology of the diseased leaves has now revealed a histological difference which makes it very clear that the light-colored areas are not normal, and this difference consists in the fact that in badly diseased plants the palisade parenchyma of the light-colored areas is not developed at all. All the tissue between the upper and lower epidermis consists of a spongy or respiratory parenchyma rather more closely packed than 
normal. In moderately diseased plants the palisade parenchyma of the light area is greatly modified. Normally the palisade parenchyma cells of a healthy plant are from four to six times as long as broad. In a moderately diseased plant, however, the cells are nearly as broad as they are long, or at most not more than twice as long as broad. As a rule, the modified cells of the leaf pass abruptly into the normal cells of the green area. In a badly diseased leaf simply looking across the surface with the naked eye shows depressions where the light areas occur, or where the leaf is mostly diseased the dark green patches are raised above the general surface."

\section{- In 1902 Woods (36) also wrote as follows:}

"Somewhat later I pointed out an important structural difference between the cells of the green areas and those of the light. In the latter, in the less pronounced cases of the disease, there is a shortening and broadening of the palisade parenchyma cells, and in the more pronounced cases there is an entire suppression of these cells, so that on simply looking across the surface of the leaf depressions are seen where the light areas oceur and apparent blisterlike development in the green areas. As a rule the modified cells pass abruptly into the normal cells of the green areas. The palisade cells of healthy leaves and of the healthy areas of diseased leaves are from three to four times as long as broad. Some plants are dark green, and these have the longest and narrowest palisade cells, closely packed with dark green chloroplasts, which seldom contain large starch grains. Other plants are much lighter in color. These have relatively broader palisade cells, approaching more in size and shape the spongy parenchyma cells of the same leaf. In both the light and the dark leaves the spongy parenchyma cells are about isodiagrametric, the diameter being about twice the length of the continuous palisade cells of the mature leaf.",

In this same paper he commented on the differences in the cell structures of the chlorotic and green areas as follows:

"The conditions which cause the disease are certainly only effective when acting on meristematic or dividing cells. It cannot be induced artificially, and never appears naturally in cells which have stopped dividing. A diseased spot, therefore, never increases in size in a leaf except as the disease cells themselves enlarge. The mosaic nature of the trouble and the fact that under some conditions the plants may grow out of the disease suggests that it must arise in such cases in the meristematic tissues behind the growing point, or where the plant is not mosaic, but evenly diseased, the pathological condition must be present throughout the cells of the growing point."'

In 1903 Iwanowski (19) published the results of extensive studies on tobacco mosaic and called attention to the error of Beijerinck who believed that the green areas was a true symptom of the disease. He says :

"When a diseased leaf is examined with care and compared with a sound one, a retardation of the development of the yellow spots is noticed; these are thinner than the greenish ones, and show a weak development on the obverse side." 
He also says:

"A cross section of a green part gives the impression of a normal sound leaf, sometimes better developed than a sound one. The palisade and spongy parenchyma tissue are conspicuously differentiated.

"We obtain a different appearance when the preparation is made from the yellow part of the leaf. In this place the leaf is thinner than the green one, in a proportion of $2: 3$. It was believed that the palisade tissue. was not yet developed, in its place we find other cells; a comparison with the green parts showing that the longitudinal walls have not been formed but are already in their development stage. The inter-cellular spaces are completely formed; so that we can differentiate at once the green from the yellow parts with which the weak tissue has correlation."

\section{In this same paper he said:}

"The parenchyma of the diseased leaves is more vigorously developed than those of the sound organs. In general the green parts seem hypertrophied and remind one of the forced development of tissue, on account of the presence of a parasite or insect injuries. This circumstance makes investigators of the mosaic diseases (Beijerinck) believe that the green spots are diseased and that the yellow are completely normal, and that they are only checked in their development or account of the deviation of the nutritive substances to the green parts of the leaves."

In this same year Bouygues (4) published a paper in which he reported the loss of the epidermis which was due probably to faulty technique.

In 1910 Westerdijk (33) published the results of studies on tomato mosaic, but the histological part did not add anything to our knowledge of the subject.

The next paper on this subject was by Melchers (28) in 1913 who made some studies on both tomato and potato. He reports that he did not find any abnormalities in the tomato, such as were described by Woods and Iwanowski for tobacco. However, he says-

“* * * at times in the yellow areas this tissue (palisade) appeared slightly less developed than usual. The yellow areas were slightly thinner than the adjacent green areas, especially in older leaves."'

\section{Concerning the potato he says-}

"A microscopic study showed that the yellow areas were thinner at all ages; in some cases they were only 90 mic. thick as compared with 120 mic. in the normal leaf. This thinness was largely due to a shortening of the palisade cells which were of a striking cuboidal form. Sections from mottled areas were easily distinguished by the shape and size of the palisade cells. The cuboidal cells began very abruptly in some sections, while in other eases there was an intergradation between them and the normal palisade cells. In the yellow areas 
as a rule, these cells were generally quite regular in shape, but sometimes there was less regularity. Their length varied from one-half to one-third that of normal cells and their thickness was usually slightly greater. The sporigy parenchyma appeared normal in all areas, except that in the yellow regions, there were somewhat fewer chloroplasts.",

In 1917 Chapman (6) published a bulletin in which he gives some attention to the histology of the tobacco leaves which showed mosaic. He agrees in general with Woods but says-

"Occasionally the dark green areas showed a more closely packed parenchyma than in normal leaves, and always the palisade was well developed and approached the normal in character. The development or non-development of the palisade layer, as Woods hinted, is dependent on the degree of severity of the disease. The lighter the attack the less are palisade cells and parenchyma tissue altered and vice-versa.",

Chapman gives illustrations of cross sections from the normal tobacco leaf and from the green and chlorotic areas of mosaic leaves. These illustrations show that the palisade cells of the green areas and the intercellular spaces of the mesophyll are reduced as compared with the normal leaf. Also that the chlorotic areas are much thinner than the green areas, that the palisade is reduced to cuboidal cells and that the mesophyll is reduced and compact.

In 1920 Doolittle (13) published the results of his studies on the mosaic disease of cucurbits in which he described the anatomy of the leaves as follows:

"When stained sections of the leaves are examined, the palisade cells of the green areas are found to be crowded closely together and to be somewhat narrow and longer than those of the normal leaf. The palisade cells of the yellowed portion on the other hand, are more nearly isodiametric and less in number per unit area than in the normal leaf.

"The spongy parenchyma of these yellowed areas is also more compact and the intercellular spaces smaller than in the green portions."

In 1922 Matsumoto (26) published the results of his studies on the azuki-bean in which he said-

"The anatomy of the diseased leaves is found to be identical with that of cucumber mosaic as described by Doolittle. The mesophyll of the dark-green parts of the diseased leaves is strikingly thicker than that of the light green or yellowed parts. The palisade cells of the former are markedly longer and narrower than those of the normal tissues. The corresponding cells of the lightgreen parts are much shorter than those of the normal ones, more or less isodiametric, and show a tendency to crowd together so closely that their intercellular spaces are almost invisible. The second important difference between these two different portions occurs in the spongy parenchyma. The spongy parenchyma of the light-green parts is also strikingly compact as compared with that of the dark-green areas. The chloroplasts of the former, as in cucumber mosaic, are slightly smaller and less in number than in the darker areas." 
In this same year Rand (29) published an extensive paper on the pecan rosette in which he says-

"Within the yellow thin areas between the larger side veins (secondary stage) the tissue is usually less developed than normal, and the cells are more closely packed together. In less severe cases the palisade tissue is well developed, but the intercellular spaces become almost obliterated. In other instances the palisade cells are differentiated, but the individual cells are greatly shortened vertically and may be only two or three times as long as broad, instead of seven to ten times, as in the normal leaf. In the most severely affected leaves with extreme variation in leaf diameter there is no differentiation into palisade and sponge tissue at all in the center of these yellow spots, but the tissue within these parts of the leaf consists entirely of closely packed, more or less isodiametric cells without conspicuous air spaces. Under these conditions the number of cell divisions may be somewhat increased, the cells remaining smaller than normal. Usually, however, the number of divisions is reduced, and in some instances a parenchyma tissue only three cells deep has been found. Occasionally the entire tissue between the margin and midrib consists of undifferentiated cells. That this lack of differentiation is not due to immaturity was shown by examination of young healthy leaves just after their emergence from the bud. Even at this young and only partially expanded stage the palisade tissue of healthy leaves was found to be well differentiated.

"In the thickened portions along the veins, or sometimes throughout the laminae in the aborted non-mottled leaves of depauperate rosettes, the size of cells may become increased in all three dimensions without essential change in ratio between spongy and palisade tissue. In some eases a slight increase in number of cell divisions also takes place. The individual cells appear abnormally healthy, and increase in leaf thickness here is due largely to increase in size of the individual cells. Along with this increase in cell size there is a reduction in size of intercellular spaces within the spongy parenchyma, and in the severely attacked leaf an almost complete obliteration of air spaces results.

"Linear leaves may or may not show a differentiation into palisade and spongy tissue, but where the palisade cells are developed they are usually shortened vertically and the spongy cells of the parenchyma are more closely packed together than the cells in healthy leaves. The average thickness of these leaves tends to be less than normal and this reduction is due partly to decrease in the number of cell divisions and partly to the shortened vertical axis of the palisade cells. The elongated shape of the leaves, however, is not due to variations in cell shape but rather to a decrease in number of cell divisions in which the central spindles are perpendicular to the midrib. This would tend to keep the cells closer to the main water supply of the leaf.",

Various other workers have called attention to the reduced thickness of the chlorotic areas and to modifications of the cell structures, but the most extensive work to date was published by Dickson (12) in 1922. His work was especially valuable because of the large number of species and varieties of plants which he used. He also appears to have been the first to report that in some cases two layers of palisade cells were developed, which he believed to be a hyper- 
plasia caused by a late or slight stimulation of the meristematic cells. In speaking of the tobacco he says-

"In a diseased leaf, however, there is a striking difference in the lamina thickness of the light and dark areas, the relative thickness being 180-200 and 270-300 microne, respectively, or a ration of 2 to 3 . This is referable mostly to the difference in development of the palisade tissue in the two cases as was shown first by Woods. In the light areas the palisade parenchyma cells do not lengthen or do so to a limited extent depending on the severity of the infection. In most cases when leaves are severely infected the cells are cuboidal or isodiametric actual measurements showing variation from 20 to 60 microns in length and 17 to 28 microns in width. The cells of the spongy parenchyma in a healthy leaf are approximately twice as long as the palisade cells are wide, but in the light areas of diseased leaves the palisade cells are approximately equal in diameter to the underlying cells. This is due to the fact that the mesophyll cells are slightly smaller than in a healthy leaf, and that the normal division of cells in the palisade region is probably inhibited to some extent while the cells are meristematic. These cells are therefore in a hypoplastic condition as far as growth is concerned and the same applies to the cell contents as will be seen later.

"By contrast the palisade cells of the dark areas are well developed and in all cases they are at least normal in size. The writer has found, however, a very common modification when the disease is severe. Instead of the palisade cells occupying a single layer there are two layers, the lower comprising cells somewhat shorter than those in the upper layer but being obviously palisade cells. In such cases the individual cells are also narrower so that equal lengths of cross section from moderately and severely diseased leaves gave palisade cells in the proportion of 6 to 10, respectively, counting the upper row only in the latter. This palisade tissue consequently occupies a relatively greater volume of the leaf and there is a considerable increase in the number of cells. Since they are well supplied with chloroplasts able to function we may assume that the photosynthetic efficiency of this tissue is increased. In view of the increase in volume it is obvious that the palisade tissue in severely diseased leaves is in a condition of hypertrophy and because of the increase in number of eells the hyperthrophy may be accounted for by assuming a condition of hyperplasia when the tissue was meristematic. Woods considered the palisade cells of the dark areas to be normal for he states that the 'modified cells pass abruptly into the normal cells of the green areas'. Chapman however, while using the term 'healthy cells' say that 'their structure may be somewhat modified by the increased functioning thrown on the healthy cells'. It is the writer's view that when infection is severe in any given meristematic cell that cell will be hypoplastic, but if it is infected later, or only slightly, then it will be stimulated either to hypertrophie growth or to hyperplasia. This would account for such instances above mentioned."

Space will not permit the quoting of Dickson's studies on other plants but in his summary he says:

"Previous studies by other authors have been concerned chiefly with tobacco and in one or two cases with tomato and potato. In these no agreement is reached except in the finding of hypoplastic palisade tissue in lighter green areas of tobacco and potato and of fewer and paler chloroplasts in those areas. 
"As a result of my studies with tobacco, tomato, potato, black henbane, petunia, pepper, sweet pea, Canada field pea, kidney bean, Windsor bean, raspberry, red clover, crimson clover, alsike clover, white Dutch clover and black medick it is clear that certain microscopic features are common to all the mosaic diseases studied. It is not to be understood, however, that in any leaf section from a diseased plant all characteristics, equally well developed, are to be observed. Much depends upon the growth rate and environment of the host plant but if sections are made from rapidly grown leaves of well-infected plants most of the following findings can easily be verified.

"There is a difference in the lamina thickness of light and dark parts of the leaf varying in amount and in the majority of cases giving a relative value of 2 to 3 , respectively, where the disease is ordinarily severe. If the infection be slight there is less reduction in thickness of the lighter green parts but if the attack be unusually severe there is more reduction in the lighter parts and an increase in thickness of such parts as are dark green. Usually the dark green is but little thicker than an ordinary healthy leaf. This reduction in leaf thickness is due to hypoplasia of both palisade and spongy mesophyll cells but more especially to the former. There are all gradations from slight hypoplasia to that in which the cells are isodiametric and can only be determined as palisade cells by their position. It would appear that the hypoplastic condition of such cells is indicated also by the fact that they are usually somewhat wider that normal palisade cells. In a healthy leaf of tobacco, for example, a spongy mesophyll cell subtends approximately two palisade cells. Allowing that there is hypoplasia of the spongy mesophyll cells their reduced size is not very marked and yet only one hypoplastic palisade cell is needed to equal one mesophyll cell. This will be referred to again, but the point of view with regard to these palisade cells is that not only are they unable to develop in length but they must have been inhibited from further division when meristematic. In leaves where the attack is mild the palisade cells are narrower and longer, in fact nearly normal.

"'The spongy mesophyll cells are also hypoplastic to a greater or less extent and when the disease is more severe they are equal in length to the width of the palisade cells above them. There is thus a very noticeable regular arrangement of the cells in the lighter green leaf parts."

"This regularity in cell arrangement necessarily reduces the proportion of intercellular space in the leaf, and by contrast there is usually an increase over normal in the intercellular spaces of hypertrophied parts.",

Rawlins and Johnson (30) in 1925 published a paper on the cytology of mosaic tobacco in which they say-

"As has been found by other workers, the palisade cells in the chlorotic tissues are shorter and more nearly square in section than those in the nonchlorotic tissues of a mottled mosaic leaf or than those in healthy leaves."

In speaking of a section made from a plant which did not shown any symptoms of disease and in which the palisade cells were well developed, they say: 
"A leaf of this age will probably never become badly mottled. At least part of the chlorotic appearance in mottled leaves seems to be due to the failure of the palisade cells in the chlorotic part to elongate. It is a common field observation that, when old plants are inoculated with mosaic virus, the older leaves do not become mottled, only the young growing leaves developing this symptom.",

In 1926 Goldstein (16) published the results of extensive studies on the cytology of healthy and diseased tobacco plants in which she says :

"I find that the presence of the virus in the early stages in the histogenie development of the leaf results in the more severe types of mosaic patterns. Sections through the diseased leaves of tobacco plants, at all stages of their development, show that histogenic development was arrested in every case by the entrance of the virus. The distribution of the virus in the tissue is indicated by the stage in histogenic development which the various cell regions show. The lighter green regions of the leaf patterns were invaded before the dark green or normal green areas, which have continued their histogenic development to a latter stage. Sections through mature leaves, infected during the final stage of leaf development, show that the pattern is due to the effect of the disease upon the cell contents. In certain areas distributed through the leaf blade, such infections of leaves in later stages of histogenic development result in the faintly mottled apperance.

"In my opinion the dark green areas represent regions which have escaped infection in the early stages of the entrance of the virus into the leaf primordium. They are able to go through their histogenic development for a time, but soon the toxins of the virus hinder the completion of histogenesis, as far as differentiation is concerned. The cells continue to enlarge, and can only do so by elongating, since they are bounded by cells which, owing to the presence of the virus, are not enlarging to any extent, and are rather rigid. When the cells of the dark regions divide, they are likewise under pressure from the surrounding light green regions which are enlarging more slowly, so that a buldging upward to form a blistered or puckered region (savoying) results.

"As indicated in this seriation of the mosaic pattern types, the anatomical structure of a diseased leaf is correlated with the stage of its development when the virus entered it. When cuboidal cells are found in the light green areas of a given leaf, infection must have occurred at a very young stage and these cells have simply remained undifferentiated. The double palisade layer of the dark green areas, when studied from the developmental and histogenic standpoint, can be shown to be characteristic of young healthy green leaves at a certain stage of their development; neither has the hyperplastic development of a second layer of cells taken place, nor has hyperplasia of the cells themselves occurred in the dark green areas; the corresponding palisade cells of a leaf of mature development upon a mature plant may be much larger both in width and length than I have ever found them to be in the dark green regions of diseased leaves." 
She also says:

"I find that Iwanowski's and Dickson's statements as to the histology of the dark green areas are not incompatible. Both conditions can be found, depending on the age of the leaf at the time when infection took place. My sections through mature healthy leaves of mature plants show that in tobaceo as in many other plants, a second layer of less elongated palisade cells may normally occur. The term hyperplasia as implying the development of a second layer of palisade cells should not be used in connection with the dark green areas of diseased tobacco leaves. These areas consist of seven layers of cells such as are characteristic of healthy mature leaves.

"The cells found in the sections of the light green areas do constitute a hypoplastic condition due to severe infection, and represent the original embryonic condition of the leaf at the time when infection took place. Cytological study of very young leaves leads unquestionably to the conclusion that the entrance of the virus interferes with the histogenic development of the leaf. Embryonic cell layers of leaf primordia, which have been given an opportunity to develop before the entrance of the virus, show a normal palisade development. Furthermore, I find that the dark green areas, contrary to the opinion of Dickson are in reality also hypoplastic, and show a cell-form condition characteristic of a young stage in development of a normal leaf. The cells in such infected leaves soon cease to differentiate, and the palisade cells have simply elongated, producing the double palisade layer whose cells never attain the size of the cells found in mature healthy leaves. In accord with Küster's (1904) view of hyploplasia, such an arrested development should be considered as representing a hyporplastic condition.",

In this same year Smith (31) published the results of her studies on mosaic diseases and leaf variegations. She states that the leaves of both healthy and diseased plants were of approximately the same age and the drawings show that these leaves were well advanced. Concerning her studies on Datura stramonium she says:

"It was found in the histological studies that neither the green nor the chlorotic areas of the mosaic-infected plants are comparable to the normal, the green being thicker than the healthy, but showing normal tissue differentiation and distribution of plastids; whereas the chlorotic areas are approximately equal in thickness to those of the healthy, but have poorly differentiated palisade tissue and show a decrease in the number of plastids."

\section{Concerning the Phytolacca decandra she says:}

"Here, as in Datura, it ean be seen that the mosaic disease modifies the entire leaf, the dark green area being thicker than normal and the ehlorotic region being reduced, particularly in the palisade layer. In this case also the healthy leaf is thinner than the dark green mosaic area but thicker than the chlorotic region. The thinness of the chlorotic sections is due chiefly to a lack of differentiation of the palisade layer."

She also reports a loss of the palisade cells in the chlorotic areas of a hybrid Aquilegia, a decrease in the thickness of the mesophyll 
and that "the healthy leaves are thinner than the dark green areas and thicker than the chlorotic regions".

In 1927 Sorokin (32) published a paper on tomato mosaic in which she agreed with the finding of Dickson. Speaking of a chlorotic region she says:

"All cells are nearly isodiametric; there is no differentiation into palisade and spongy parenchyma; the intercellular space volume is very limited; the epidermal cells are hardly distinguishable from the parenchyma cells. The chlorotic regions in less severely diseased leaves are characterized by the fact that the first row of parenchyma cells are slightly longer than those of the other three or four rows." * * * "The spongy parenchyma and intercellular spaces are present and the epidermal calls are somewhat hypertrophied."

So far as the writer is able to determine from the descriptions and illustrations, none of the investigators with the exception of Goldstein have given careful attention to the ages of the leaves which they have studied. 'In many of these papers it is very evident that the studies were confined to the old leaves in which the tissues were differentiated so far as possible.

It is unnecessary to call the attention of the readers of this paper to the fact that a young leaf is composed of undifferentiated cells which undergo rapid differentiation with the growth of the leaf, resulting in the well known tissues of the leaf, long before the leaf is full sized. It is reasonable to suppose that the reaction of the plants would vary somewhat with the age and development of these meristematic cells and more or less well developed tissues at time of coming in contact with the active agent which causes the disease. In studies recorded in this paper and in others by the writer, a series of leaves from the youngest in which the disease could be detected to the oldest in which the pattern was sufficiently well defined to permit the selection of material, were studied. Comparative studies were made between the chlorotic and green areas of the same leaf and between chlorotic areas of diseased plants and leaves of the same age from healthy plants. It is the opinion of the writer that these studies have made it possible to follow some of the reactions of the plants to the diseases with a fair degree of accuracy.

In general it may be said that chlorotic areas are thinner than the normally green areas and that these areas vary in thickness, not only in different plants but in different leaves, and also in different areas of the same leaf. In general it may also be said that the histological variations are not so pronounced in the monocotyledonous as in the dicotyledonous plants.

The differences in the thickness of the leaves of diseased and 
healthy plants ean be detected in very early stages of their development by studying buds from corresponding parts of diseased and healthy plants. Variations will be found frequently in a single leaf from a mosaic plant. Furthermore the cells in these thin areas are usually smaller than in normal leaves of approximately the same ages. These points are shown in figures $11 a$ and $11 b$ in which it will be readily seen that the diseased leaf (fig. 11 b) is thinner and the cells smaller than in the healthy leaf (fig. $11 a$ ). As the leaves grow older the leaves from the healthy plant will develop the normal structure (figs. $12 a, 13 a \& 14 a$ ). The leaves from the diseased plant increase in size but the cell structure of the chlorotic areas are never normal. Sometimes they retain the structural character of undifferentiated cells throughout the life of the plant (fig. $12 b$ ) while in other cases they approach the normal (figs. $13 b, 14 b$, \& $14 c$ ). Sometimes they are almost normal in structure but modifications of the chloroplasts indicates that they are diseased.

Studies on other tobacco plants gave about the same history except that in most cases the chlorotic areas were thinner than the normal green leaves of the same age and the palisade poorly developed. The studies in general lead the author to believe that the poor differentiation in the first two leaves studied (figs. $11 b, \& 12 b$ ) as compared to the next two leaves studied (figs. $13 b \& 14 b$ ) was due to the fact that the first two leaves were younger at time of attack than the last two leaves.

The tomato plants used in these studies were infected with the same virus as the tobacco plants. The infections were severe and the symptoms very pronounced on the upper leaves; but the symptoms gradually disappeared with the increased age of the leaves. Several plants were used for study but all the drawings were made from the green and chlorotic areas of a single plant. The studies began with the youngest leaves in which the patterns could be detected with certainty. By this time, the palisade cells had developed in the green areas (fig. $15 a$ ) but were very difficult to detect in the chlorotic areas (fig. $15 b$ ). The chlorotic area was slightly thinner than the green area (figs. $15 a, b$ ).

In the second leaf the development of the green area may be considered normal and complete (fig. $16 a$ ). Sections from two chlorotic areas from opposite sides of the midrib of the same leaf (figs. $16 \mathrm{~b}, \mathrm{c}$ ) showed a variation in thickness, which is very common in all species that the writer has studied. The cell structure in both sections was very uniform, the palisade undeveloped and the intercellular spaces small. 
The green area from the third leaf (fig. $17 a$ ) was somewhat under developed as compared with the preceding leaf (fig. 16a). The section from the chlorotic area (fig. $17 b$ ) was slightly thinner than the green one (fig. $17 a$ ), the palisade under developed and the mesophyll quite uniform.

The green part of the fourth leaf was thinner than the green parts of the third and second leaves but the structure may be considered normal or nearly normal. Sections from two chlorotic areas of this same leaf showed variations in thickness and structure (figs. $18 b, c$ ). In one (fig. $18 b$ ) there was practically no differentiation into palisade and mesophyll, while in the other (fig. 18c) the differentiation was practically the same as in the green part.

The fact that the green areas of the thirde and fourth leaves (figs. $17 a \& 18 a$ ) were rather thin and under developed may or may not have been due to the disease. The author has noted that there may be considerable variation in the thickness of leaves of apparently healthy plants, regardless of ages. The partial development of the palisade cells in the chlorotic areas of the third and fourth leaves (figs. $17 b \& 18 b$ ) as compared with the lack of development in the first and second leaves (figs. $15 b \& 16 b$ ) is apparently due to the age of the leaves at time of attack. However it will be noted that sections from two chlorotic areas (figs. $18 b \& c$ ) of the fourth leaf show great variations in the development of the palisade. It is reasonable to suppose that this variation in development is due to an unequal distribution of the virus in the leaf.

The diseased cowpea plants used in these studies were very severely infected. Two sections from young normal leaves (figs. $19 a \& b$ ) and one section from an old leaf (fig. $20 a$ ) show the line of development. In the very young leaf (fig. $19 a$ ) the cell structure is undifferentiated. The differentiation is shown in figures $19 b$ and $20 a$. The chlorotic areas in leaves of about the same age from diseased plants show remarkable variations in both thickness and structure (figs. $19 c, d, \&$ $20 b, c, d, e)$. Here as in the tomato we find that two chlorotic areas from the same leaf may show variations in both thickness and structure. This is illustrated in figures $19 c$ and $d$ which are from the same young leaf. Figure $19 c$ shows what is to be expected in a severely infected leaf; there is practically no differentiation. Fig. $19 d$ shows some differentiation but the condition of the chloroplasts indicate the infection. The variations in an older leaf are shown in figures $20 b$, $c$ and $d$. The section shown in figure $20 b$ was from a slightly chlorotic area. The thickness is the same as in the normal leaf (figure $20 \mathrm{~b}$ ), the palisade consists of two layers of cells and the mesophyll 
cells are somewhat smaller and more compact than in a normal leaf or green area of a diseased leaf. Figures $20 c, d$, $e$, were made from sections from old, severely diseased leaves. They are thinner than a normal leaf of the same age (fig. $20 a$ ). The cells are rather large but meristematic in character except in figure $20 d$ in which there is a tendency towards the development of a palisade. These variations are probably due to the age of the leaves at the time they were penetrated by the active agent, or to the virulence of the active agent, or to unequal distribution of the active agent.

\section{DISCUSSION}

It is very generally recognized that the active agent is distributed throughout all parts of the plant, except the seeds, in which it has been found in only a few cases. It is also very generally recognized that the chlorotic areas are thinner than the green areas of the same leaf or a normal leaf of the same age. These studies show that these chlorotic areas may vary in thickness, even in the same leaf. In brief a leaf from a mosaic plant of tobacco, tomato or cowpea may show variations in thickness and structure ranging from a green area of normal thickness to a chlorotic area which is very thin and composed of undifferentiated mesophyll supported by an imperfect fibrovascular structure. All gradations in thickness and structure may occur between these two extremes. In some cases the only modification of structure is the formation of two layers of palisade cells.

So far as the author has been able to learn, Woods was the first to call attention to the reduced thickness of the chlorotic areas and this has been confirmed by most investigators since that time. $\mathrm{He}$ also called attention to "the fact that in badly diseased plants the palisade parenchyma of the light colored areas is not developed at all. All the tissue between the upper and lower epidermis consists of a spongy or respiratory parenchyma rather more closely packed than normal". He also stated that "the conditions which cause the disease are certainly only effective when acting on the meristematic or dividing cells".

Since that time many investigators have confirmed Wood's opinion that chlorotic areas were thinner than the green areas and that the palisade was undeveloped. However, no one appears to have been impressed with the idea that the structural variations were due to the action of the active agent on the meristematic tissue until the publication of Dickson's paper (12) in 1922. He said:

"It is the writer's view that when the infection is severe in any given 
meristematic cell that cell will be hypoplastic; but if it is infected later, or only slightly, then it will be stimulated either to hypertrophic growth or to hyperplasia.",

The writer agrees with the first statement of Dickson but not with the latter. The studies on which this paper is based indicate that the active agent which causes the disease is inhibitory. It produces a hypoplasia by inhibiting the differentiation of the meristematic tissues. The writer does not find hypertrophy in any of the cases studied, which are usually classified under the general term of mosaic.

So far as the writer has been able to learn Goldstein (16) was the first to assert that "the virus interfered with the histogenic development of the leaf" and that "the distribution of the virus was indicated by the stage in histogenic development". The studies of the writer very generally confirm the results reported by Goldstein.

It is very evident to the writer that the active agent inhibits the growth and differentiation of the meristematic cells. It is also evident to the writer that the active agent does not cause a change on any of the leaf tissues after they have completed their normal development. The variations in the histogenic structures found in the different chlorotic areas as recorded in this paper may be due to any one of several causes:

1. The amount of the virus or active agent injected into the plant and carried to the meristematic region.

2. The growth activity of the host plant at the time.

3. The relative virulence of the active agent.

4. The relative age of the tissue at time when it comes in contact with the active agent.

5. The unequal distribution of the active agent throughout the leaf.

The growth of the tissues of chlorotic and green areas is not the same. In some cases the differences in growth are so great as to cause a deformity. This is especially noticeable in the tobacco where it results in the formation of pockets in the green areas. This pocketing is evidently due to the fact that the growth in the chlorotic areas has been slowed up while that of the green areas appears to be normal or nearly normal.

The differentiation of the tissues in the chlorotic areas is inhibited and the growth and division of the cells is slowed up to some extent. The result is that the chlorotic areas increase in size as a result of the division and growth of the cells. However, there is no evidence to indicate that it increases in size as a result of the invasion of the 
active agent after the tissues are mature. Woods (36) appears to have been the first to call attention to this point when he said:

"A diseased spot, therefore, never increases in size in a leaf except as the diseased cells themselves enlarge."

The writer of this paper confirmed this idea for sugar cane in a paper published in 1926 (10) by the following statement:

"These areas increases in size with the growth of the leaves, but so far as the writer has been able to determine they do not eneroach on the surrounding tissues and do not coalesce. The inerease in size appears to be by cell division and growth and not by infection of surrounding cells."

\section{CHLOROPLASTS}

It is very generally recognized that the very young leaves of most plants are white or very light green and that those which have a mosaic disease show very faint or no mosaic patterns whatever until they have been exposed to sunlight and begin to turn green. In the ease of normal plants the young leaves become uniformally green very rapidly when exposed to sunlight. In the case of plants infected with mosaic, certain areas become normal green very quickly while certain others remain light green or yellowish for a time displaying the well known pattern of mosaic and then in most cases gradually become green until the pattern almost or completely disappears. This has been observed by a number of writers and appears to be true for most plants. The most notable exceptions are the lettuce as reported by Jagger and the Abutilon hirtum which will be discussed by the writer in a later paper. Jagger $(20)$ in his discussion of the lettuce mosaic says:

"The first symptom of disease was a yellowish discoloration along the smaller veins of the younger expanded leaves. This symptom was usually evident for only a few days, giving way to a general yellowish, discolored appearance of the whole plant. All gradations of discoloration occurred from very marked to conditions not distinguishable with certainty from normal."'

This statement indicates that the discolorations become more pronounced with age which is not in harmony with most descriptions of mosaic symptoms; but he further says:

"Often plants that showed marked discolorations, mottling, and stunting soon after beçoming diseased would later seem to recover in part and to make a more or less normal growth with only slight discoloration and mottling.",

This last statement indicates that the patterns disappear in some cases and the plants tend to become green with age as described for 
most mosaic diseases. In the Abutilon hirtum which will be discussed in a later paper some of the spots become slightly greener with age while others remain chlorotic.

'i'his tendency for the chlorotic areas to become green with age and exposure to sunlight led the writer to doubt the generally accepted idea that the chlorotic condition was the result of a disintegration of the chloroplasts as stated by several writers. If the chloroplasts undergo disintegration, these chlorotic areas ought to become more chlorotic instead of green. Therefore, the writer began a series of studies on this phase of the mosaic problem some years ago and the results were first presented in a paper published (9) in 1925. This was followed by a paper (11) which was read before the Philadelphia meeting of the American Phytopathological Society in 1926 and published in $1927^{\circ}(10)$. These papers were received with more or less differences of opinion. The writer having made his studies almost entirely on sugar cane, which had not been used by any of the other workers on this phase of the subject, decided to continue the studies and to use a number of other species of plants. The plants used were the common red canna (Canna indica), tobacco and tomato, all of which have been studied by other workers, cowpea which has been studied to some extent and Abutilon hirtum. The readers will note that the sugar cane and canna are both monocotyledonous while all the other are dicotyledonous. This may be of some importance because in the first two the leaves are rolled while in all the others they are folded and because the cell structures are somewhat different.

Before giving the results of these studies on chloroplasts, it is desirable to give a brief review of the literature to date. Mayer (27) referred to the chloroplasts in mosaic of plants and said that mosaic was a disease of the plasmatic cell contents. Köning (23 \& 24) reported a disorganization of chloroplasts and a disappearance of the cell walls, which leads the writer to suspect that he studied old leaves and that the conditions were due to other causes. The statement that the chloroplasts were disorganized or disintegrating appears to have been generally accepted until the writer of this paper published (9) evidence to the contrary in 1925 (see page 88).

Beijerink (3) defined the mosaic of tobaceo as a disease of the ehlorophyll bodies which finally became a disease of the plasmatic contents of the cells. However, he did not give an explanation of his results. The writer is of the opinion that he also was working with old leaves.

Woods (35) in the conclusions of his first paper makes the very 
definite statement-"Chlorophyll is destroyed rapidly by oxidizing enzymes, of which two groups are recognized,-oxidases and perioxirases", but he does not explain why the chlorotic areas become green with age.

In 1902 he said (36):

"That the disease is not primarily of the chloroplasts, as Beijerinck thought, is evident from the fact that in the less pronounced cases the chloroplasts, though fewer in number are not decreased in size or activity. * * * In some pronounced cases the chloroplasts are light colored or wholly without color."

Iwanowski (19) published a paper in 1903 in which he said:

"If we now turn our attention to the cell contents, there is a lack of chloroplasts which are not regularly distributed in the palisade parenchyma. Investigation on the live-stage shows swollen ehloroplasts which have the appearance of big drops with green, fine circles around them. Sometimes these drops fill the whole cell, rarely the chloroplasts are scattered and the cell contents is of a pale green color. As in the beginning of the observation and because of the rapid preparation of the solution, such formations appear rarely, we have to accept that they are more properly an artificial product, a continuation of the resistance capacity of the chloroplasts of the yellow parts in comparison with the green. In the last ones no such scattering of the chloroplasts has been seen.

"The chloroplasts on the yellow parts have a pale yellow color, with a granular structure. At first there is no vigor, cuts on new leaves treated with iodine showed a great difference; in the green parts an intense color, in the yellow, not a vigorous granule. Examinations with the naked eye showed that a diseased leaf after being treated with iodine showed color in dark blue and yellow sections, while the dark blue sections corresponding to the green parts. Later on, the vigor shows on the yellow parts also.",

Baur (1) reported in 1904 that in Abutilon thompsoni there was no evidence of a causal organism but that the plastids in the chlorotie areas were reduced in size and number.

In 1910 Westerdijk (33) reported the chloroplasts of tomato mosaic as slightly smaller than normal, yellowish and containing but little starch. Melchers (28) reported in 1913 that the chloroplasts in the chlorotic areas of mosaic potatoes were fewer and of a pale yellowish green. Doolittle (13) reported in 1920 that the chloroplasts in the cells of the chlorotic areas of the cucumber were smaller than in green leaves and that they were located so very close to the cell walls as to be almost invisible.

In 1915 Clinton (7) said:

"Very frequently, especially where the chlorosis is of the mosaic or variegated type, it seems to start in the very young tissues, and not after the leaves are fully grown. 
In 1920 Doolittle (13) published a paper on the mosaic of cucurbits in which he said:

"The chloroplasts of the cells of the yellowed portions are decidedly smaller than in normal cells and are often pressed so closely to the walls of the cells as to be almost invisible. In contrast to this the chloroplasts in the dark-green areas are so large and numerous as to seem to fill the cells. The vascular elements of mosaic show little variation from the normal.',

Kunkel in 1921 in his paper (25) on a mosaic disease of corn says :

"Even before the leaves unfold and while they are still quite white the diseased areas appear translucent and can readily be distinguished from the portions of tissue, which on exposure to light will become deep green. As the leaf unfolds in the light and becomes green the outlines of the diseased spots or stripes become more clearly marked. The light color of the diseased areas is due to a failure of these portions to develop the normal green color rather than to a fading of the green color after it has once been produced."

Dickson (12) in his studies on a large number of plants frequently refers to the reduced number of chloroplasts in the chlorotic areas but shows that he is a believer in the disintegration theory by several statements. In his discussion of the tobaceo mosaic he says:

"The carbohydrate content is not the same in light and dark-green areas is indicated by the iodine test. The chloroplasts and grains in the lighter-green areas take on a brown stain, even when there is little obvious change in the chlorophyll apparatus, and the amount of carbohydrate is less because of the fewer chloroplasts.

"The chlorotic condition of the lighter areas is not due to lack of iron in the plastid as is clearly indicated in the following tests.",

After giving these tests he continues:

"The only cells in which this was difficult to demonstrate for individual plastids were those containing many tiny hyaline masses resulting from their break down. It is possible of course, that in such cases we have a hypoplastic condition under which the normal plastids did not develop originally but it appears more probable from my observations that this is a case of degeneration."

In his discussion of the potato mosaic he says :

"The chloroplasts of the cells of the light areas are fewer in number and paler in color than in the dark green but there are fewer instances of chloroplast degeneration than in tobacco. In the dark green tissues the chlorophyll content is always at least equal to the normal and sometimes above that of healthy tissue."

Again in his summary of the results of microscopic studies (p. 49) he says:

"“Corresponding with the hypoplastic condition of the cells there is a gradation of hyploplasia and degeneration of the cell contents. Cells, slightly 
affected as far as growth is concerned may be different from healthy cells only in the slightly paler green of the chlorophyll while the chloroplasts appear to be present in nearly normal number. With increase in severity of effect on cell size there is a very definite reduction in the number and of depth of color of the chloroplasts and in some instances they are also reduced in size."

\section{Johnston (22) says in speaking of sugar cane that-}

"This mottling character is most clearly seen in the inner newly developed leaves, often fading out in the mature leaves. It is not seen in any very young shoots."

\section{$\mathrm{He}$ also says-}

\section{"A gradual disappearing of the mosaic in old leaves."}

In 1925 Rawlins and Johnson (30) published their studies on the cytology of mosaic tobaceo in which they said:

"From the drawings it is evident that in this leaf the palisade cells and their chloroplasts are well developed. A leaf of this age will probably never become badly mottled. At least part of the chlorotic appearance in mottled leaves seems to be due to the failure of the palisade cells in the chlorotic part to elongate. It is a common field observation that, when old plants are inoculated with mosaic virus, the older leaves do not become mottled, only the young growing leaves developing this symptom."

In the writer's first paper on this subject in which the studies were restricted almost entirely to sugar cane attention was called to smaller number and small size of the chloroplasts in the chlorotic areas as compared with the green areas and normal cane. The writer said:

"A study of the cells of these leaves shows that the chloroplasts are more numerous in the dark geen than in the light green areas. Therefore, it appears that in the case of the light green areas the formation of the chloroplasts is inhibited but that with the exposure to sunlight this inhibition is gradually overcome.

"The chloroplasts in the white or yellow areas were fewer in number and smaller than in the green areas.

"The small chloroplasts of the mosaic cells are usually spoken of as having undergone a process of degeneration. The writer has studied the chloroplasts in the very young unrolled leaves and is satisfied that these chloroplasts are undeveloped rather than disintegrated. They have never reached normal development. Furthermore a study in a series of leaves from those just unrolling to the outermost on a plant shows that the chloroplasts of both normal and mosaic cells increase in size after being exposed to light. These changes which are apparently due to age or light are so pronounced that there is very little difference in size of chloroplasts in old leaves of diseased plant and the chloroplasts 
in a leaf of the same age from a healthy plant. The writer is very doubtful if disintegration over occurs in case of primary infection (i. $e$. infection from the seed).",

In the paper (11) read before the Phliadelphia meeting (1926) of the American Phytopathological Society the writer expressed the opinion that-

"The chloroplasts are not destroyed nor even injured by the diseases. Their development however is inhibited."

In the more complete paper (10) on this subject the writer said:

"The chloroplasts in the sheathing cells of a healthy plant are large and the markings well defined as compared with the chloroplasts from the corresponding cell of a diseased plant which are small and with poorly defined markings. The chloroplasts in the ordinary mesophyll cells of a healthy plant are large and regular as compared with the chloroplasts from the corresponding cells of a diseased plant. However, as previously stated, the chloroplasts in the chlorotic areas in the older leaves of a diseased plant are very nearly or quite normal in appearance. No disintegration of the chloroplasts was observed in any case except in very old leaves which were decaying from old age or in tissues which were decaying as a result of attacks of fungi.",

The writer also said:

"The tendency of leaves of diseased plants of both sugar cane and tobacco to become more or less uniformily green with age and exposure to sunlight is no doubt due to tendency of the chloroplasts in the cells of the chlorotic areas to increase in number and size. This could not possibly be the case if the chloroplasts were undergoing disintegration."

In 1926 Eckerson (15) reported the finding of flagellate organisms living in and destroying the chloroplasts in plants infected with tomato mosaic.

In this same year, Jones (21) described a mycetozoan (Plasmodiophora tabaci) from tobacco plants. He says:

"Disintegration of chloroplasts apparently is the first visible response on the part of the cell to the presence of the organism. Later the cell walls disintegrate and disappear."

In the following year Sorokin (32) published a paper on "Phenomena Associated with the Destruction of the Chloroplasts in Tomato Mosaic" in which she gives a short review of the literature and a lengthy discussion of her experiments.

In the summary of the paper Sorokin says:

"The chloroplasts are destroyed through the dissolution of the proteins of the stroma. This fact is easily demonstrated by direct observation of the living material and by microchemical tests. The same is confirmed by study of the 
material fixed under the microscope, or fixed and stained by usual cytological methods.

"The normal chloroplasts are rather solid. The first indication of a pathological condition is the appeearance of rapidly moving hyaline bodies within the chloroplasts. The movement of these bodies is possible only after liquification of the stroma of the chloroplasts has taken place. Therefore it is assumed that a proteolytic enzyme, possibly secreted by an organism, is present. An increased osmotic concentration results inside of the chloroplasts, and water is taken in from the surrounding medium. Finally, the entire body of the chloroplasts goes into solution and, if sufficient water is present in the surrounding medium, spherical transparent vesicles result.

"The sphere represents a membrane resulting from the digested chloroplast in which the digestion products and water are retained, the whole being surrounded by a surface film at the interface. The spheres give negative protein reactions, and are soluble in alcohol, acetone, or acids. They are soluble in weak alkali. They can be fixed and stained by methods used in the study of the inclusion of the animal virus diseases."

In this same year Bremer (5) published the results of his studies on the cytology of the stripe disease of sugar cane and other plants in which he gave some attention to the chloroplasts. He reports a reduction in the size of the chloroplasts in some species and varieties but not in others. In one place he says:

"The chlorophyll grains are very irregularly scattered and are absorbed to a large extent by the stripe-diseased body"

which indicates a belief in the theory of disintegration.

In another place he says:

"I also found that, in most cane species, the chlorophyll had a lighter green color, in the light-green areas, the chlorophy grains not having reduced in size. In Betoeng I Rokan and Kapoer I Rokan, both species showing entirely white stripes on the leaves, most of the ehlorophyll grains had remained small, owing to the disease. There even were chlorophyll grains that could hardly have been seen when strongly magnified, while they were entirely wanting in many cells. The very small chlorophyll grains were colorless. In mosaic Hippeastrum and Eucharis, I found also that in eases where the color of the leaves was lighter green, the chlorophyll grains had remained smaller than in healthy plants."'

However, his figure No. 1 shows a healthy cell in which the chloroplasts are large and a diseased cell in which they are small.

In 1927 Hoggan published the results of her studies on the virus diseases of Solanaceous plants (18) in which she made the following statement:

"Where the external symptoms of mottling or chlorosis were marked, the chlorophyll had changed from green to yellow, and the plastids were reduced in size, in severe cases of disease sometimes disintegrating and apparently breaking up into small particles. In leaves infected when very young, the chloroplasts did not develop normally but remained small and fewer in number than in the 
healthy cell. When placed in water, these plastids often swelled up to form colorless vesicles as described by Iwanowski (19), and it is thought possible that this may have some bearing on the formation of the 'spheres' reported by Sorokin (32).",

This brief review of the literature will show that the theory of disintegration of the chloroplasts as advanced by Köning and Beijerinck was very generally accepted by most workers without question until 1925 when the writer (9) advanced the theory of inhibition.

This theory of inhibition of the chloroplasts was well received by some workers but was not accepted by others. This difference of opinion led to the more extensive studies which are reported in this paper. However, before taking up the additional data we will review the results of the work on sugar cane as given in the authors last paper. In this connection the attention of the reader is called to the fact that the leaves of the sugar cane do not have a well defined layer of palisade cells such as is found in the leaves of most plants. However, the leaves of the sugar cane do have two distinct types of parenchyma cells: (1) a single layer of long tubular cells forming a sheath around the fibro-vaseular bundles, and (2) ordinary parenchyma cells which are irregular in size and form and constitute the true mesophyll of the leaf.

Cross sections of leaves of healthy plants beginning with the inner leaves (figs. $1 a, 1 c, 1 e$ ) * show that the number and size of the chloroplasts is practically the same throughout the series from oldest to youngest leaves. This is also shown in longitudinal sections through these sheathing cells (figs. $3 a, 3 c, 3 e$ ) and in sections through the ordinary mesophyll cells (figs. $5 a, 5 c, 5 e$ ). But similar sections through the chlorotic areas of mosaic leaves of the same ages and positions as the leaves on the healthy plants showed that the chloroplasts were few and small in the cells of the inner leaves but increased in size and number in successive leaves from the youngest or intermost to the oldest or outermost leaf (figs. 2, 4 and 6). These studies were made on a number of different plants and the results were always the same. There was no evidence of disintegration of the chloroplasts except in the very old leaves in which some of the cells were abnormal as a result of old age or the attacks of fungi. All these studies were made from sections cut from leaves fresh from the plant and studied immediately and from sections made from leaves which had been killed and fixed a few minutes after collecting.

It appears to the writer that this tendency of the chloroplasts to

* This series includes five leaves. The drawings have been made from numbers 1,3 and 5. However, studies have been made on a series of seventeen leaves from a single plant. 
become normal in number and size is due to the exposure to sunlight rather than to age. Both normal and diseased canes were germinated and grown so far as possible in a dark room and both remained chlorotic.

The mosaic disease was discovered in our plots of red canna (Canis indica) but unfortunately all the plants were diseased and it was impossible to compare the normal with the mosaic plants. The patterns disappeared very quickly with age and exposure to sunlight, so that is was impossible to find the patterns on the fifth leaf. However, it was very easy to compare section from the green and light colored areas of the four youngest leaves. Sections were made from the leaves that were just unrolling as soon as the patterns were sufficiently distinct to show the boundaries and from the second, third and fourth leaves. No sections were made from the fifth leaves because the patterns were practically lost and because they were infected with rust fungi (Puccinia cannae (Went.) P. Henn.)

An examination of sections (fig. $7 a$ ) from the green parts of the innermost or youngest leaves showed numerous, well developed chloroplasts while an examination of sections (fig. $10 a$ ) from the green parts of the fourth leaf showed no differences or only slight increases in size and number of chloroplasts. An examination of sections (fig. $7 b$ ) from the chlorotic areas of the inner or youngest leaf showed very few and small chloroplasts, while an examination of sections from the light areas from the second (fig. 8), third (fig. 9) and fourth (fig. $10 \mathrm{~b}$ ) leaves showed a gradual increase in the number and size of the chloroplasts from the innermost or youngest to the oldest or outermost of the leaves. This is in harmony with the conditions recorded for the leaves of the sugar cane and indicates that there is a true inhibition of the development of the chloroplasts in the chlorotic areas which is partially overcome by age and exposure to sunlight.

Sections were made from a series of leaves of a healthy tobacco plant beginning with very small leaves and ending with leaves about seven inches in length (figs. $11 a, 12 a, 13 a, 14 a$ ) showed a gradual increase in the number and size of the chloroplasts. This differs from the sugar cane and canna in the fact that the chloroplasts are fewer and smaller in the young than in the old leaves. A study of sections from the chlorotic areas of corresponding leaves from diseased plants showed that in the youngest leaves (fig. $11 b$ ) there were no chloroplasts, in the second leaf there were a few small chloroplasts (fig. $12 b$ ), while in the third leaves there was an increase in number and size of the chloroplasts (fig. $13 \mathrm{~b}$ ) but that the increase was not so 
great as in the corresponding leaves from healthy plants (figs. $12 a$, $13 a$ ). However, in the fourth leaves from the diseased plants (figs. $14 b, 14 c$ ) the chloroplasts were almost equal in number and size to those in the healthy leaf (fig. 14a). The presence of the palisade layer of cells the third and fourth leaves (figs. $13 b, 14 b$ and $c$ ). The short palisade cells in $14 c$ indicates a more severe infection than in 14 b. The tendency of the chloroplasts to increase in size and number with age and exposure to sunlight is in harmony with the preceding studies.

In the study of the tomato plants there was some doubts as to whether any of the plants were absolutely free from the disease. Therefore, it was considered advisable to compare sections from the green and chlorotic areas of the same plant. The youngest leaf in this study was not so young as the youngest leaf used in the tobacco studies as shown by the fact that the palisade in the green area of the youngest leaf (fig. $15 a$ ) was farther advanced than the palisade in the green area of the youngest leaf of the tobacco (fig. 11 $a$ ). The chloroplasts in the green areas of the tomato plant were very numerous and fairly regular in size in all the leaves from the youngest to the oldest (figs. $15 a, 16 a, 17 a, 18 a$ ). However, the cell structure of both the third and fourth leaves (figs. $17 a$ and $18 a$ ) indicates a slight infection as compared with the second leaf (fig. $16 a$ ). In the chlorotic area of the first leaf (fig. $15 b$ ) there were no chloroplasts; in the chlorotic areas of the second leaf (fig. $16 \mathrm{~b}$ and $c$ ) the chloroplasts were few and small. In the section from a chlorotic area of the third leaf (fig. $17 b$ ) which showed a palisade layer, indicating late or slight infection, the chloroplasts were larger and much more numerous than in the second leaf. Sections from two chlorotic areas of the fourth leaf (figs. $18 b$ and $c$ ) show an increase in number and size of chloroplasts. These sections also show a condition which is quite different in both the tobacco and the tomato in that the structural development is more advanced in one than in the other, which the writer interprets as indicating that the infection was either more severe or earlier in the one than in the other. It should also be noted that in the section from a chlorotic area in which the palisade was well developed (fig. 18c) the chloroplasts were fully as abundant as in the sections from green areas (fig. $18 a$ ) but that they were much smaller. In this as in the preceding, the study of the sections indieate's an inhibition of the chloroplasts which is partially overcome with age and exposure to sunlight.

The studies on the cowpea were less extensive than on the other plants but included both healthy and diseased plants. The very 
youngest normal leaf studied did not show any differentiation into the palisade and mesophyll yet the chloroplasts were numerous and large (fig. $19 a$ ). In a slightly older normal leaf in which the palisade was fairly well developed the chloroplasts were equally numerous and larger (fig. $19 \mathrm{~b}$ ). In a fully developed normal leaf the chloroplasts were abundant and considerably larger (fig. $20 a$ ). Two sections (figs. $19 c$, and $d$ ) from a young mosaic leaf of about the same age as the second normal leaf (fig. $19 b$ ) showed quite different conditions although they were from the same chlorotic area. In one (fig. $19 \mathrm{c}$ ) the palisade was very slightly developed and the chloroplasts few, small and very irregular in size. In other sections from the same area (fig $19 d$ ), the palisade was almost normal, the chloroplasts almost as abundant as in the section from the normal leaf (fig. $19 b$ ) but very irregular in size. A section (fig. $20 b$ ) made from the green part of a severely infected leaf showed the same thickness as the section from the normal leaf (fig. $20 a$ ) but the chloroplasts were fewer and irregular in size. Three sections made from chlorotic areas of the same diseased leaf (figs. $20 c, d, e$ ) showed that these areas were less than one-half as thick as the normal leaf (fig. $20 a$ ) or the green areas of the diseased leaf (fig. $20 b$ ) and that the palisade in all cases was under developed. The number of the chloroplasts varied in three sections but they were smaller than in the normal leaf. These studies also show inhibition of the chloroplasts but that the inhibition is overcome with age and exposure to sunlight. They also show that the disease varies in different parts of the same leaf as in the tobaceo and tomato which may be due to the age of these areas at time of infection or to severity of infection.

A study of the chloroplasts in a series of leaves from the youngest to the oldest in which the mosaic patterns ean be distinguished shows very clearly that the chloroplasts are fewer and smaller in the chlorotic areas than in the green areas of diseased plants or than in the leaves of normal green parts of corresponding ages. They also show that the chloroplasts increase in size and number with age and exposure to sunlight. It should also be noted that there are variations in different areas of the same leaf and in the same area. These variations are apparently dependent on the age of the various areas of the leaves at time of infection or on the severity of these infections or on both. The fact that the leaf is not of a uniform color indicates variations of infection of some kind. The writer is inclined to believe that the active agent spreads unevenly through the leaf and that those areas which are attacked earliest or most severely by the active agent show the greatest amount of inhibition. 
These studies on the plastids indicate that in the case of the normal plant and in the green parts of the diseased plants, the chloropilasts are well developed when the leaves open. There is some increase with age but it is not marked. The plastids in the chlorotic areas are few in number and small in size but increase rapidly in number and size with age and exposure to light, and in some cases become almost normal. The writer failed in finding any evidence of disintegration of any kind in either the chloroplasts or cell walls.

Iwanowski (19) figures large circles or spheres and the writer has found the same thing in both tobacco and sugar cane. It was impossible to trace any connection between them and the plastids and they appear to be quite different from the spheres described by Sorokin (32).

In 1926 Beauverie published a paper (2) on the degeneration of chloroplasts, especially in parasitised parts in which he also discussed degeneration as provoked by artificial methods but the author of this paper is unable to determine to what extent his results are comparable to the results described by the students of virus diseases.

The writer found many plastids that appeared to be swollen and either empty or filled with a colorless fluid. They varied in form from spherical to spindle shaped. These were formed in abundance in both diseased and apparently healthy tissues.

Very little has been done in the way of chemical studies on the mosaic diseases of plants but there are two papers that have a bearing on the work of the author. In 1919 Colón (8) published a paper on the mosaic disease of the sugar cane in which he said:

"Now, the absorption spectra obtained for the alcoholic (ethyl) solution of chlorophyll from newly yellow-striped young leaves did not in our tests and under the same conditions exhibit any differences from the absorption spectra obtained for the alcoholic (ethyl) solution of healthy young leaves.

"Should there have occurred any decomposition of the chlorophyll in the diseased leaves, the absorption spectra obtained form the examination of the alcoholic solution of their chlorophyll would not have, in the first place, been identical with the absorption spectra similarly obtained from healthy leaves. New bands or a modification of the old bands would in all probabilities have been noted, since other cane pigments and many decomposition products of chlorophyll are known to have characteristic absorption spectra. The fact that the decomposition of the chlorophyll would, in the ease of the sugar cane, have developed in an acid medium would have defined all the more the ehanges to be expected since the acid decomposition products of chlorophyll are fairly well known.", 
In 1928 Dunlap (14) published a paper which he summarized as follows :

“ 1 . The mosaic disease of tobaceo reduces the chlorophyll $(a-b)$ content below that of normal plants.

" 2. A lower-than-normal chlorophyll content is characteristic of mosaic tobacco plants at all stages of growth.

“' 3 . The amount of green pigment in any mosaic leaf of a tobaceo plant is below normal.

"4. The clorophyll content of young tissues is somewhat more seriously affected by tobaceo mosaic than older tissues.

" 5 . Older tobaceo plants, after infection with mosaic virus, were found to contain subnormal amounts of chlorophyll, especially in the leaves that developed after infection.

"6. The total ehlorophyll content of mosaic tobaceo plants is seriously reduced."

The results given in these two papers appear to be in harmony with the work of the writer of this paper.

Motile bodies were found in the cells of tobacco, tomato and sugar cane. They were found in the mesophyll, epidermal and hair cells of both diseased and healthy plants. They were never found in the chloroplasts as described by both Eckerson and Sorokin.

\section{SUMMARY}

1. This paper is a record of comparative studies on mosaic and healthy plants of sugar cane, canna, tobacco, tomato and cowpea. They deal entirely with the cell structure and cell contents of the chlorotic areas as compared with the green areas of the same plants and with healthy plants. They do not include studies of lesions. The comparisons in every case were made on tissues of corresponding ages.

2. The cell structure of a very young leaf of a normal plant is very uniform, but the differentiation begins very early and is practically complete long before the leaves are full sized.

3. The chlorotic areas of mosaic leaves are thinner than the green areas of the same leaves or than normal leaves of corresponding ages.

4. The active agent inhibits the differentiation of the cell structure from the time that the two come in contact. If the active agent comes in contact with the meristematic tissue at an early period in its development, the structure remains undifferentiated; if at a later period, the tissues remain in the stage of development at time of attack.

5. The spread of the active agent through the leaf appears to be 
very uneven, which accounts for the mottling and the variations in development in different parts of the leaf.

6 . The reaction of the leaf may depend on the age of the leaf at the time of infection, to the virulence of the virus or to the amount of virus; but the fact that we find variations in both thickness and cell structure in a single leaf and sometimes within a single area indicates that there may be an unequal distribution of the virus throughout the plant or throughout an organ of the plant. This is substantiated by the many records of plants (especially tobacco plants) in which one side only showed the symptoms and of leaves in which the symptoms were more severe on one side than on the other.

7. There is no reason to believe that the cell structure is modified by the virus or active agent. The tissue is inhibited in its development and remains at practically the same stage as when attacked by the virus. There is some growth but it is rarely if ever as rapid as in the green areas or in normal leaves.

8. There is no evidence that the chlorotic area increases in size as a result of the spread of the virus into the green cells adjacent to the chlorotic areas. The chlorotic areas increase in size as a result of cell division and growth of chlorotic areas.

9. The variations in growth of tissues in the bloating of the green areas or pocketing which is so common in mosaic tobacco and to the various deformities in other plants.

10. The development of the plastids is inhibited in both size and number. In the very young, growing leaves, it is difficult to locate them in either fresh or stained material but they develop rapidly with age and exposure to sunlight. The mosaic pattern gradually fades and in many cases cannot be detected in the older leaves.

11. The chloroplasts increase in size and number with age and exposure to sunlight.

12. The author did not find any evidence of disintegration of the chloroplasts.

13. In cases of non-infectious chlorosis, the plants did not become green with age and the chloroplasts did not inerease in size and number with age and exposure to sunlight.

LITERATURE

1. Baur, E., Zur Aetiologie der Infektiösen Penachierung. Ber. Deutsch. Bot. Gesell. 22: 453-460 (1904).

2. Beauverie, IM. J., Sur les Modes Degenerescence des Chloroplastes, Particulierement dans le Parasitisme. Comptes Rendus Acad. des Sciences. 183: 141-143 (1926). 
3. Beijerick, M. W., Verhandehingen der Köninklijke Akademic van Wetenschappen te Amsterdam. Deel 6: No. 5. (See also Centb. f. Bakt., Par. etc., II. 5:27-33 (1900).

4. Bouyges, H., Sur la Nielle des Feuilles de Tabac. Competes. Rendus 137: 1303-1305 (1903).

5. Bremer, G., Een Cytologisch onderzock van Strepen-Ziekte bij suikerriet en Andre Planten. Archief. Suik Med.-Ind. Meded. 11 : 337-371 (1926).

6. Chapman, G. H., Mosaic Disease of Tobaceo. Mass. Agr. Expt. Station, Bull. No. 175 (1917).

7. Clinton, G. P., Chlorosis of Plants with Special Reference to Calico of Tobaceo. Conn. Exp. Sta. Rept. for 1914 (1915).

8. Colón, E. D. The Absorption Spestrum of the Chlorophyll in Yellow-Striped Sugar Cane. Journ. of the Dept. of Agri. of Porto Rico. 3: 43-46 (1919).

9. Cook, Mel. T. Histology and Cytology of Sugar Cane Mosaic. Journ. of the Dept. of Agriculture of Porto Rico. 9:5-20 (1925).

10. The Effect of the Mosaic on the Content of to Plant Cell. Journ. of the Dept. of Agric. of Porto Rico. 10: 229-238 (1926). (Issued in 1927).

11. - Some Effects of Mosaic on the Contents of the Cell. Abst. Phytopathology 15: 57 (1927).

12. Dickson, B. T., Studies Concerning Mosaic Diseases. MacDonald College. Tech. Bull. No. 2:1-108 (1922).

13. Doolittie, S. P. 'The Mosaic Disease of Cucurbits. U.S. Dept. of Agriculture Bull. 879 (1920).

14. Dunlap, A. A., Effects of Mosaic upon the Chlorophyll Content of Tobaceo. Phytopathology 18:698-700 (1928).

15. Eckerson, S. H., An Organism of Tomato Mosaic. Bot. Gaz. 81: 204-208 (1926).

16. Goldstein, B., A Cytological Study of the Leaves and Growing Points of Healthy and Mosaic Diseased Tobacco Plants. Bul. Torrey Bot. Club. 53:499-600 (1926).

17. Heintzel, K., Contagiose Pflanzenkrankheiten ohne Microben unter besondener Berücksichtingung del Mosaikkrankheit der Tabaksblatter. Inang. Diss. Univ. Erlangen. pp. 1-45 (1900).

18. Hoggan, I. A., A Cytological Studies on Virus Diseases of Solanaceous Plants. Journ. of Agri. Res. 35:651-671 (1927).

19. Iwanowski, D., Ueber die Mosaikkrankheit del Tabak-pflanze. Zeitschrif. f. Pflansenkh. 13: 1-40 (1903).

20. Jagger, I. C., A Transmissible Mosaic Disease of Lettuce. Jour. of Agri. Res. 22: 737-739(1921).

21. Jones, P. IM., Structure and Cultural History of a Mycetozoan Found in Tobacco Plants with Mosaic-Like Symptoms. Bot. Gaz. 81: 446-459 (1926).

22. Johnston, J. R., The Mosaic Disease of Sugar Cane in 1923. Pamphlet. United Fruit Co., 25 pp.

23. Koning, C. J., Die Fleckenoder Mosaikkrankheit des Hollandschen Tabaks. Zeitschrf. f. Pflanzerkh. 9:65-80 (1899). 
24.

Del Tabak Etudien uber seine Kultur und Biologie. Amsterdam und Leipzig. p. 71-86 (1900) Reviewed in Centrabt. f. Bakt. 6: 657 (1900).

25. Kunkel, L. O., A Possible Causative Agent for the Mosaic Disease of Corn. Hawaii S. P. A. Bull. Ser. III, pl. 1. pp. 44-58 (1921).

26. Matsumoto, T., Some Experiment With Azuki-Bean Mosaic. Phyto. 12 : 295-297 (1922).

27. Mayer, A., Ueber die Mosaikkrankheit des Tabaks. Landw. Versuchs-station, 32:451-457 (1886) Review in Journ. Mycology, $7: 382-385$ (1894).

28. Melcers, L. F., The Mosaic Disease of the Tomato and Related Plants. Ohio Naturalist 13: 149-173 (1913).

29. Rand, F. V., Pecan Rosette. Its Histology, Cytology and Relation to Other Chlorotic Diseases. U. S. Bureau of Plant Industry. Bull. 1038 (1922).

30. Rawlins, T. E., and Johnson, James., Cytological Studies of the Mosaic Disease of Tobacco. Amer. Jour. of Bot. 12:19-32 (1925).

31. Smith, F. F., Some Cytological and Physiological Studies of Mosaic Diseases and Leaf Variegations. Annals of Missouri Botanical Garden. 13:425-484 (1926).

32. Sorokin H., Phenomena Associated with the Destruction of the Chloroplasts in Tomato Mosaic. Phytopathology. 19:363-379 (1927).

33. Westerdijk, Joha., Die Mosaikkrankheit der Tomaten. Medeelingen uit het Phytopathologisch Laboratorium. "Willie Com. melin Scholten". Amsterdam. Maert. pp. 1-19 (1910).

34. Wood, A. F., The Destruction of Chlorophyll by Oxiding Enzymes. Central f. Bakt., Parasi. u. Infek., II Abt. V. Band. pp. 745-754 (1899).

35. - Inhibiting Action of Oxidase Upon Diastase. Science, N. S., $11: 17-19$ (1900).

36. Observations on the Mosaic Disease of Tobacco. U. S. Bureau of Plant Industry. Bull. 18, (1902).

\section{EXPLANATION OF PLATES}

\section{Plate III}

Figs. $1 a, c, e$. Cross sections of normal leaves of sugar cane. a. leaf just open; $c$. 3rd. leaf; $e$. 5th leaf. The large cells are sheathing cells which lie next to the fibro vascular bundles. Note that the chloroplasts are normal and practically the same throughout.

Figs. $2 a, c, e$. Cross section from corresponding leaves from mosaic plant. Note that the chloroplasts are few in number and small but improve with age. 


\section{Plate IV}

Figs. $3 a, c, e$. Longitudinal sections through sheath cells of same as Fig. 1.

Figs. $4 a, c, e$. Same for mosaic plants.

\section{Plate V}

Figs. $5 a, c, e$. Section through parenchyma or mesophyll cells. Same as 1 \& 3 .

Figs. $6 a, c, e$. Same as $2 \& 4$.

\section{Plate VI}

Fig. $7 a$.

Fig. $7 b$.

Fig. 8 .

Fig. 9.

Fig. $10 a$.

Fig. $10 b$.

Fig. $11 a$.

Fig. $12 a$.

Fig. $12 b$.

Figs. $12 a \& b$.
Fig. $11 b$.

Canna green part. First leaf rolled. All leaves diseased.

Ćanna chlorotic part. First leaf rolled.

Canna chlorotic part. Second leaf unrolled.

Canna chlorotic part. 3rd leaf unrolled.

Canna green part. 4th leaf unrolled.

Canna green part. 4th leaf unrolled.

\section{Plate VII}

Tobacco. Normal leaf in bud. Slightly younger than $11 b$.

Tobacco. Mosaic leaf in bud. Note that the cell structure of $a$ and $b$ are practically the same. Also that there are plastids in $11 a$ and none in $11 b$.

Tobacco. Normal leaf. About 2 inches in length.

Tobacco. Mosaic leaf. Less than 2 inches in length. Same age. Note the difference in thickness and that $12 a$ has the palisade tissue. Also the difference in the chloroplasts.

\section{Plate VIII}

Fig. $13 a$.

Fig. $13 b$.

Fig. 13.c.

Tobacco. Normal leaf. About 31/2 inches; rather thin.

Tobacco. Mosaic leaf. About $3 \frac{1}{2}$ inches. Note that these two leaves are practically the same except that development of the chlorophyll is better in $a$ than in $b$.

Tobacco. Mosaic leaf. Same age as $13 \mathrm{~b}$. The infection more severe and palisade poorly developed.

Plate IX

Fig. $14 a$. Tobaceo. Normal leaf. About $6 \& 8$ inches.

Figs. $14 b \& c$. Tobacco. Mosaic leaf. About $6 \& 8$ inches. The disease in both $b$ and $c$ is mild; the palisade is well developed but the chloroplasts reduced. 


\section{Plate X}

Fig. $15 a$.

Fig. 156 .

Fig. $16 a$.

Figs. $b$ and $c$. From same section of leaflet. One on one side of midrib and one on other. Note difference in structure and chloroplasts. Also compare with $16 a$ and with $15 a$ and $b$.

\section{Plate XI}

Fig. $17 a$. Fig, $17 b$.

Fig. $18 a$. Figs. $18 b, c$.

Tomato leaf. Green part. Youngest leaf.

Tomato leaf. Chlorotic part. Youngest leaf. Note the difference in cell structure and chloroplasts.

Tomato leaf. Green part. 2nd leaf.

Tomato leaf. Green part. 3 leaf.

Tomato leaf. Cholorotic part. 3 leaf. This leaf was attacked later than $16 \mathrm{a}$. The structure is slightly reduced and the chloroplasts decidedly reduced.

Tomato leaf. Green part. 4 leaf.

Tomato leaf. Chlorotic part. 4 leaf.
Figs. $16 b$ \& $c$. Tomato leaf. Chlorotic part. 2nd. leaf.

Fig. $b$ was attacked early and $c$ late. Note difference in structure. Compare chloroplasts with $18 a$.

\section{Plate XII}

Fig. $19 a$. Fig. $19 \mathrm{~b}$. Fig. $19 c$. Fig. $19 d$.

Fig. $20 a$. Fig. $20 b$.

Fig. $20 c$. Fig. $20 d$. Fig. $20 e$.
Cowpea. Very young leaf. Normal.

Cowpea. Young leaf. Normal.

Cowpea. Young leaf. Mosaic.

Cowpea. Same leaf. Mosaic.

Compare structure and chloroplasts; $c$ and $d$ are from same leaf which shows that the disease was more severe in one part than in the other.

\section{Plate XIII}

Cowpea. Old leaf. Normal.

Cowpea. Old leaf. Mosaic. Green part. Note the double layer of palisade and compare chloroplasts. The disease in this ease was very mild.

\section{Plate XIV}

Cowpea. Old leaf. Mosaic. Severe.

Cowpea. Old leaf. Mosaic.

Cowpea. Old leaf. Mosaic.

Note that the cell structure in $c, d \& e$ is abnormal but that the chloroplasts tend to recover.

$$
\mathrm{o}-\mathrm{O}-\mathrm{O}
$$


PI.ATE III
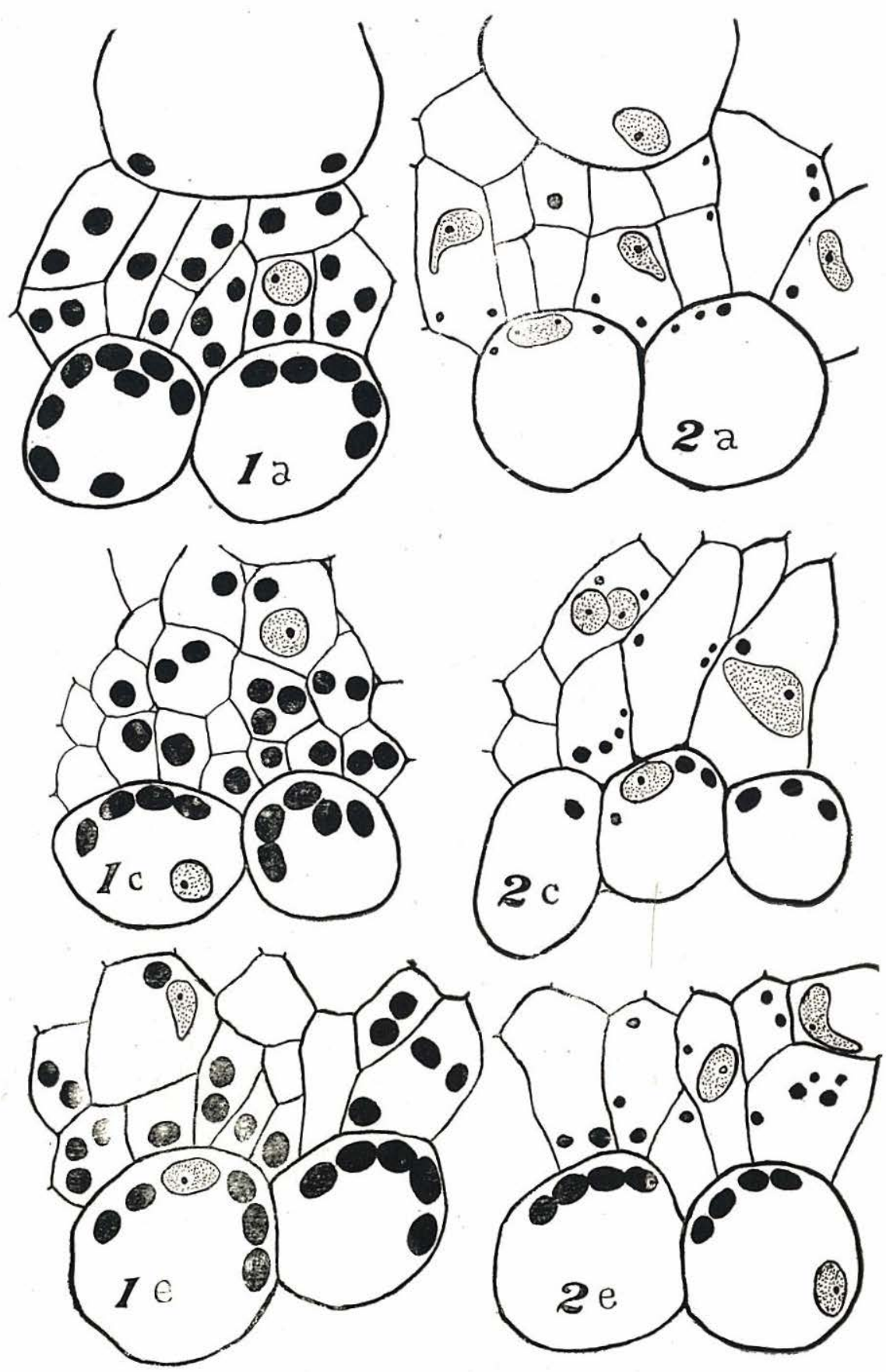
PLATF IV
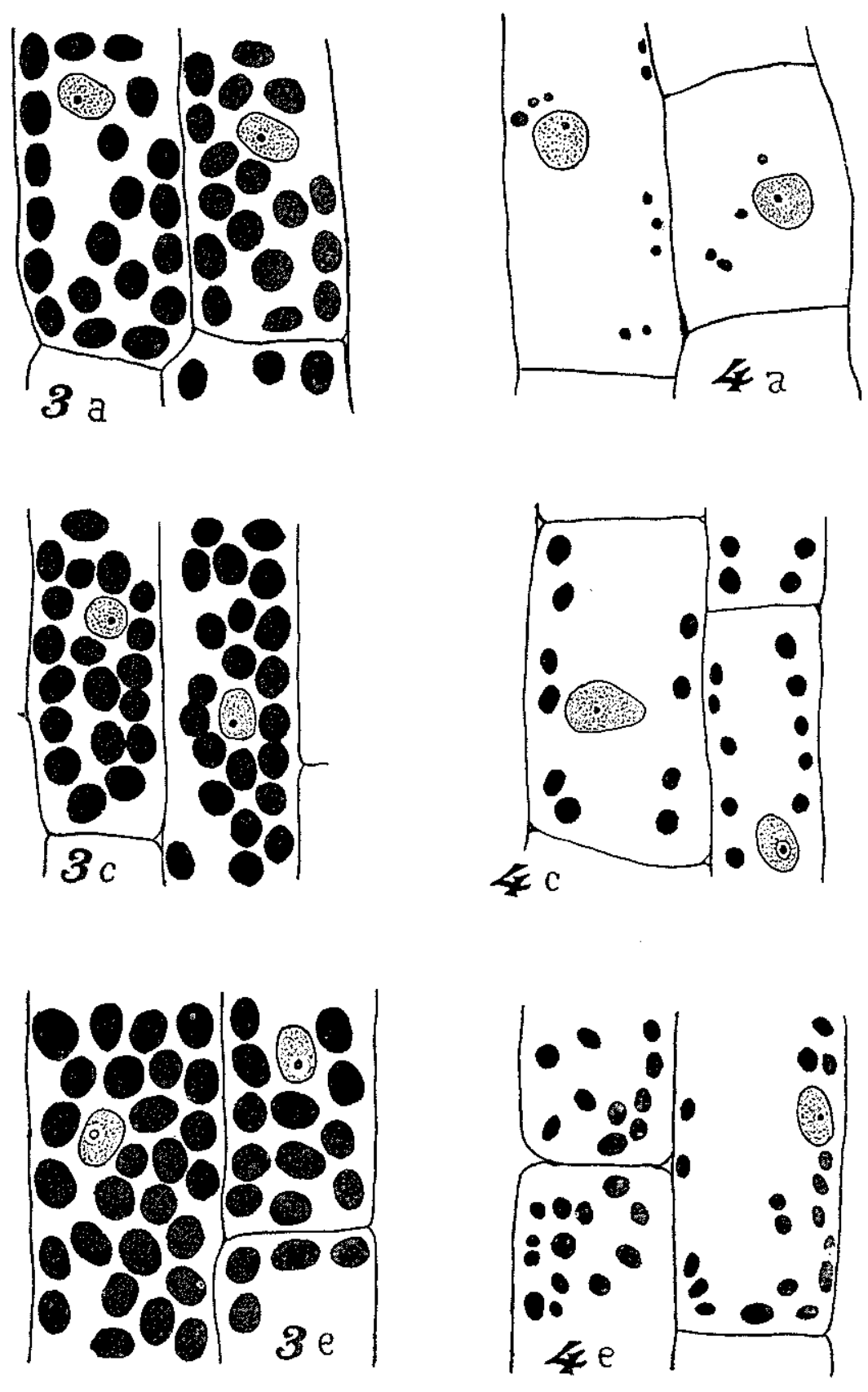


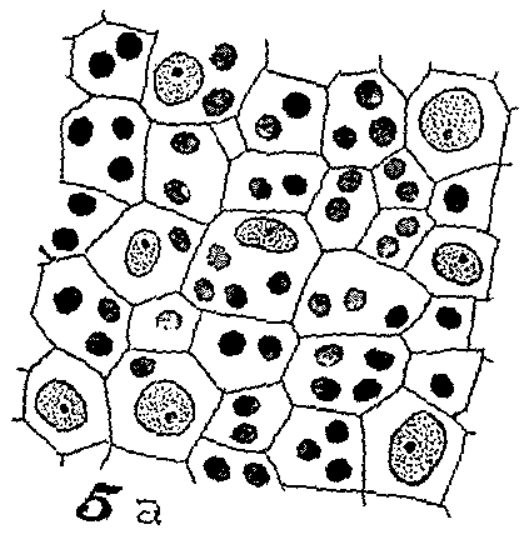

PI.ATE V
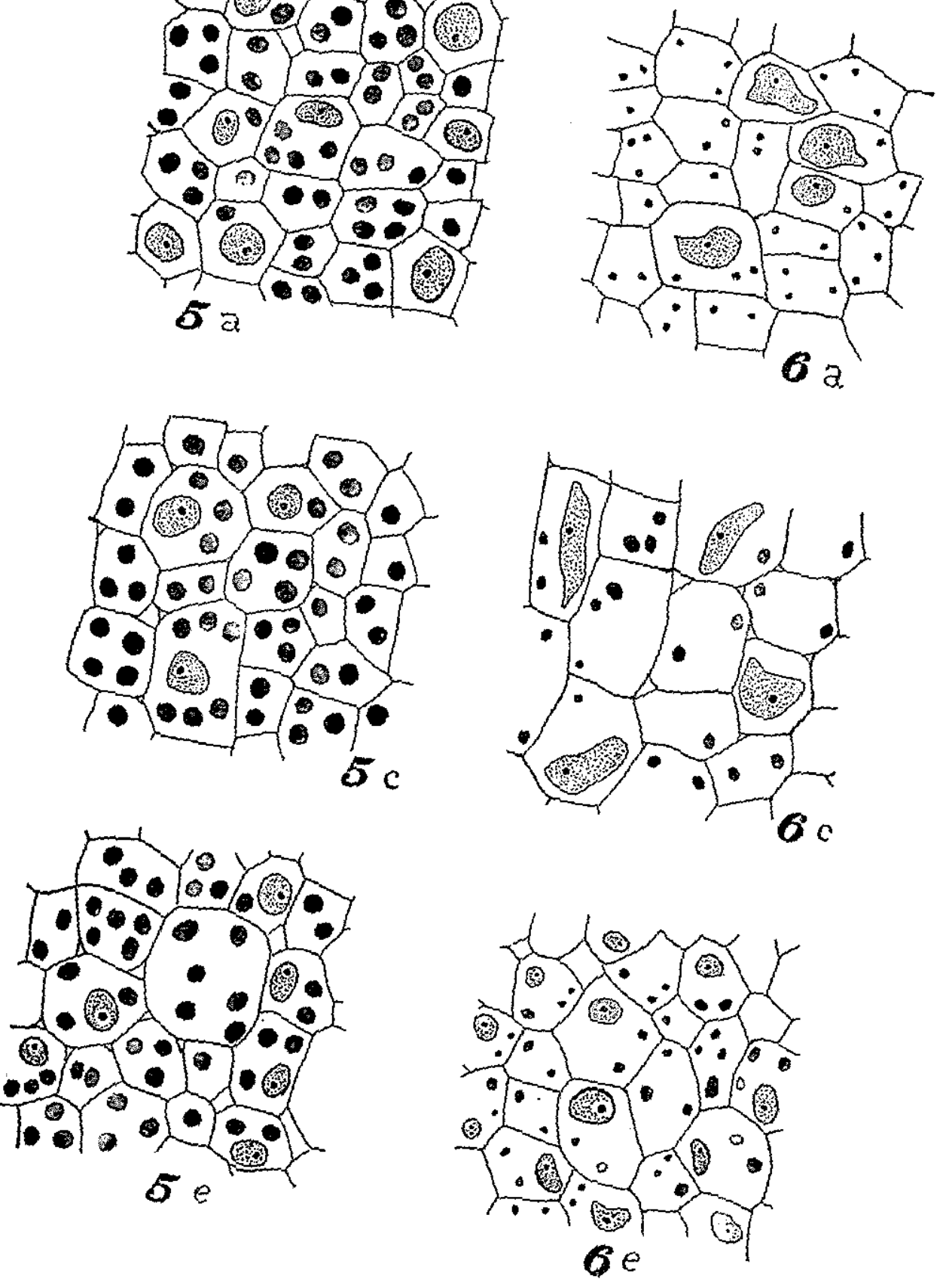
PLATE VI
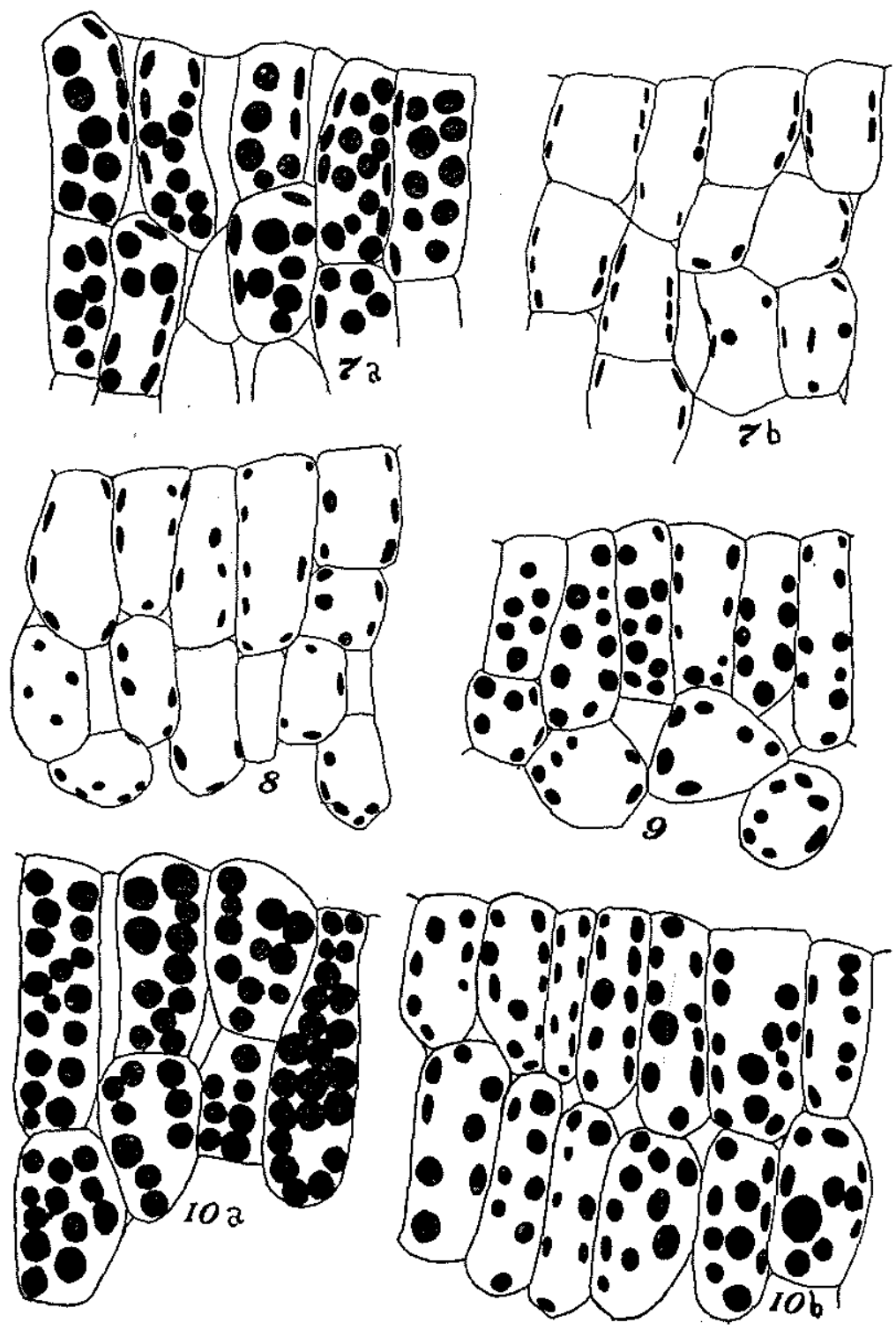


\section{PLATE VII}

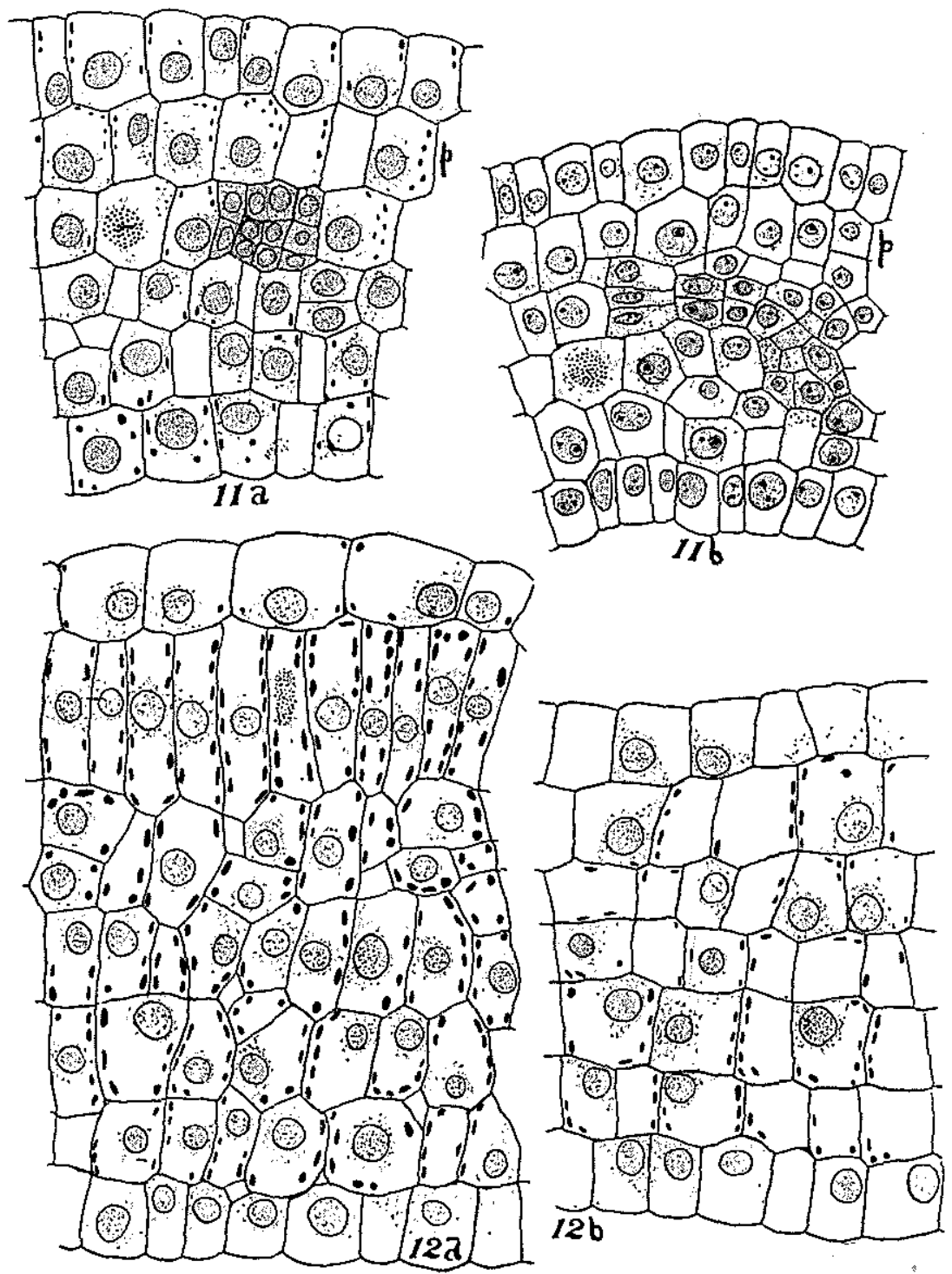


PLATE VIII

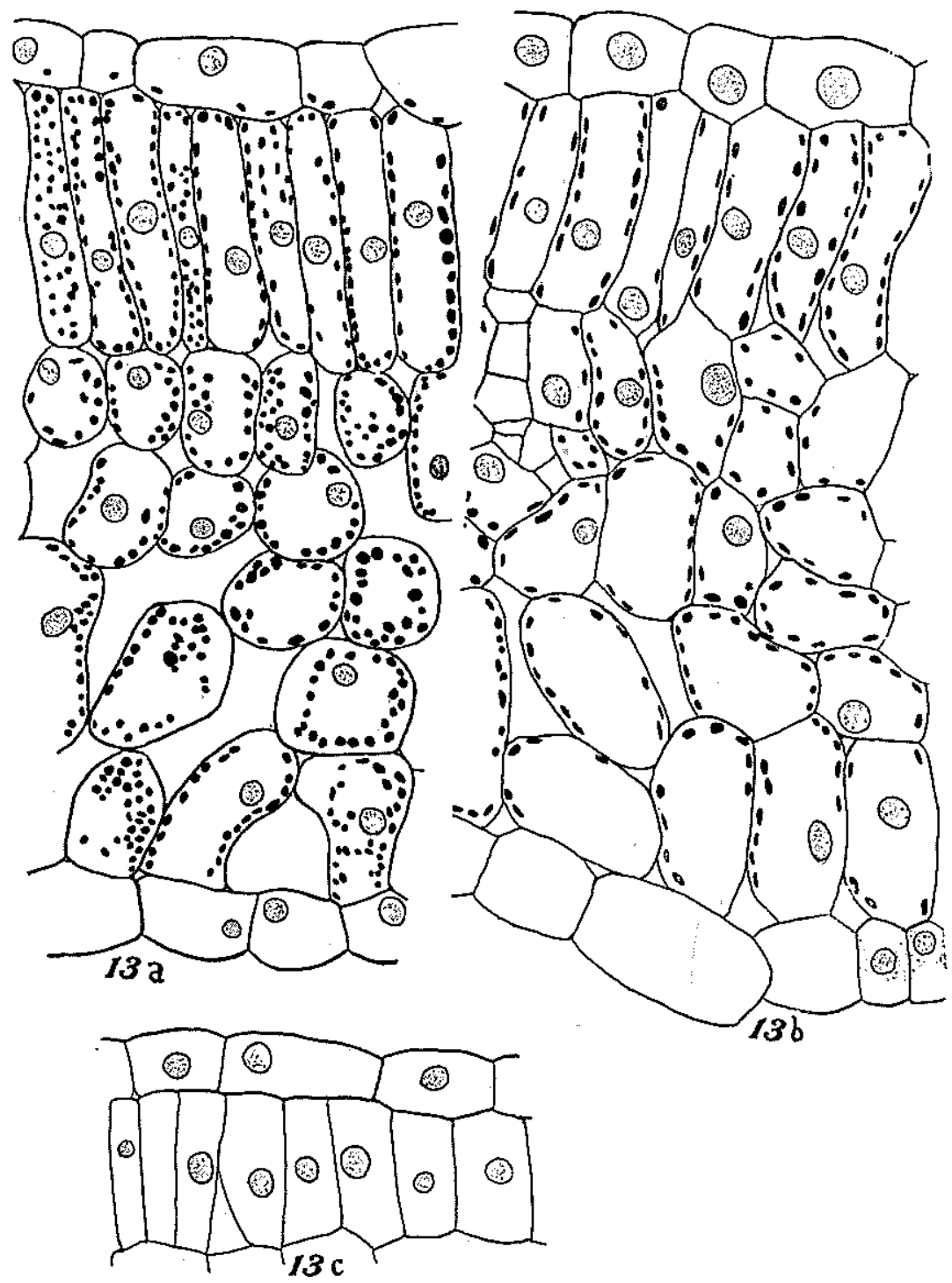


PLATE IX
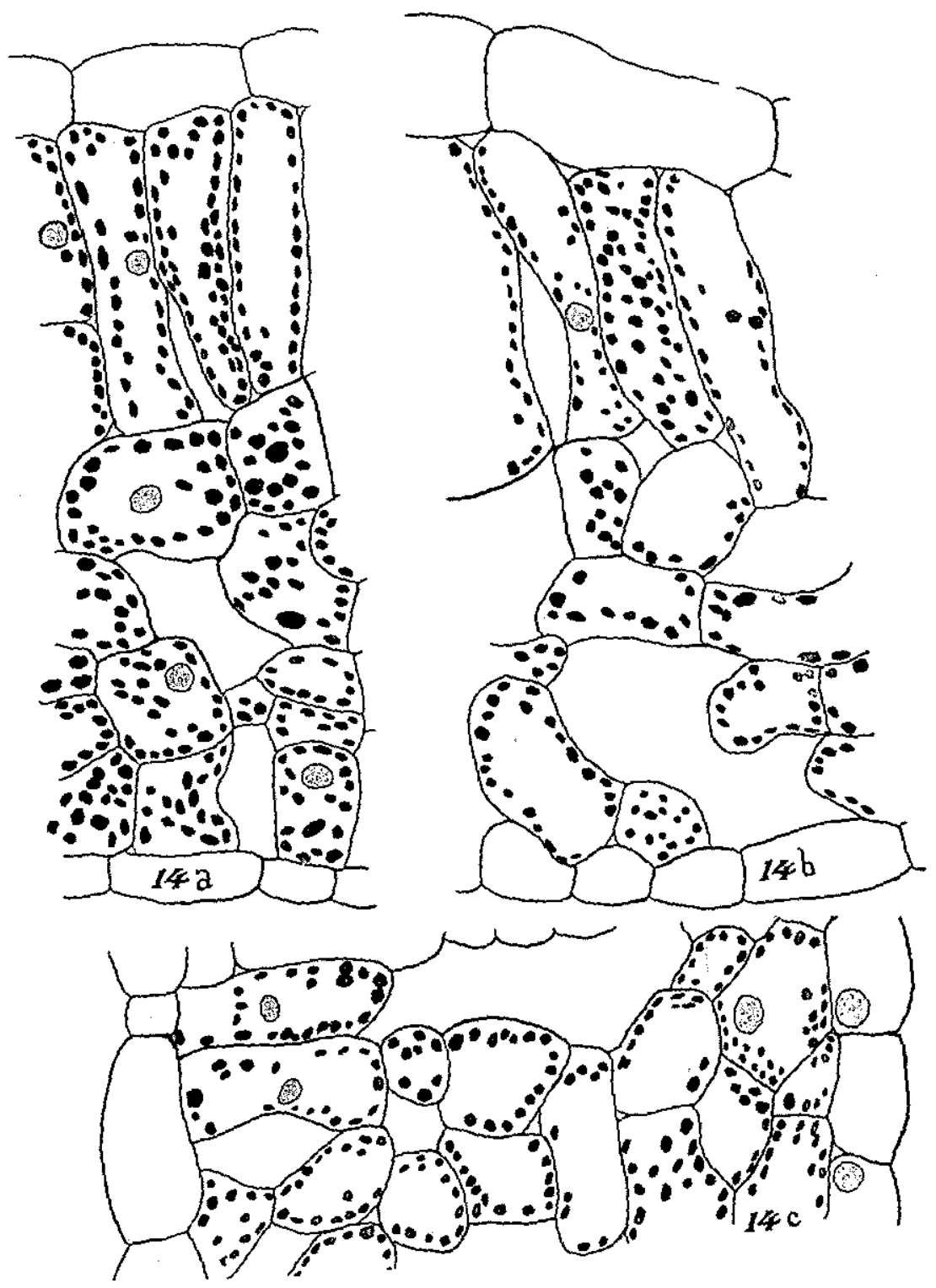
PI_ATE $\mathrm{X}$
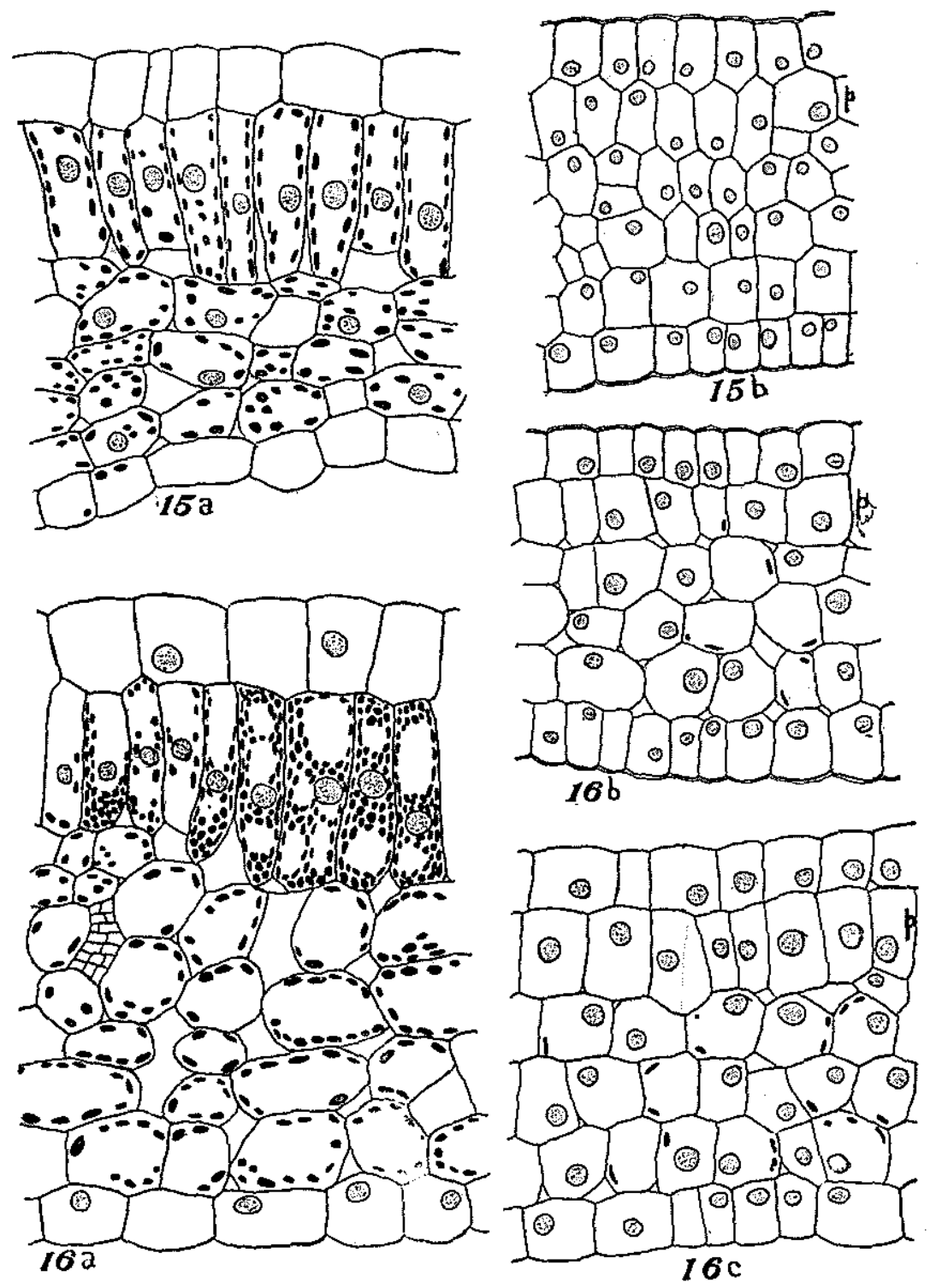

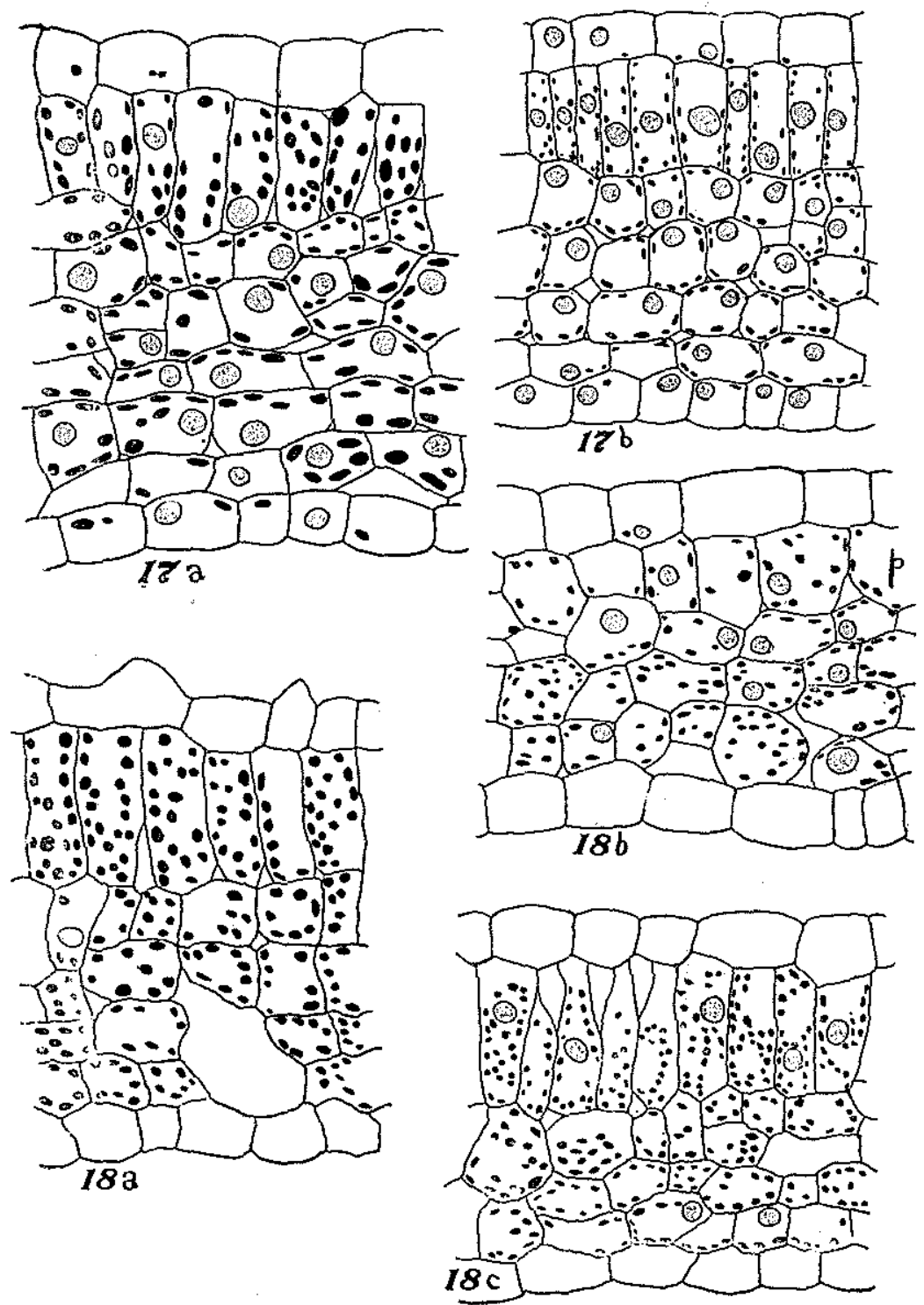

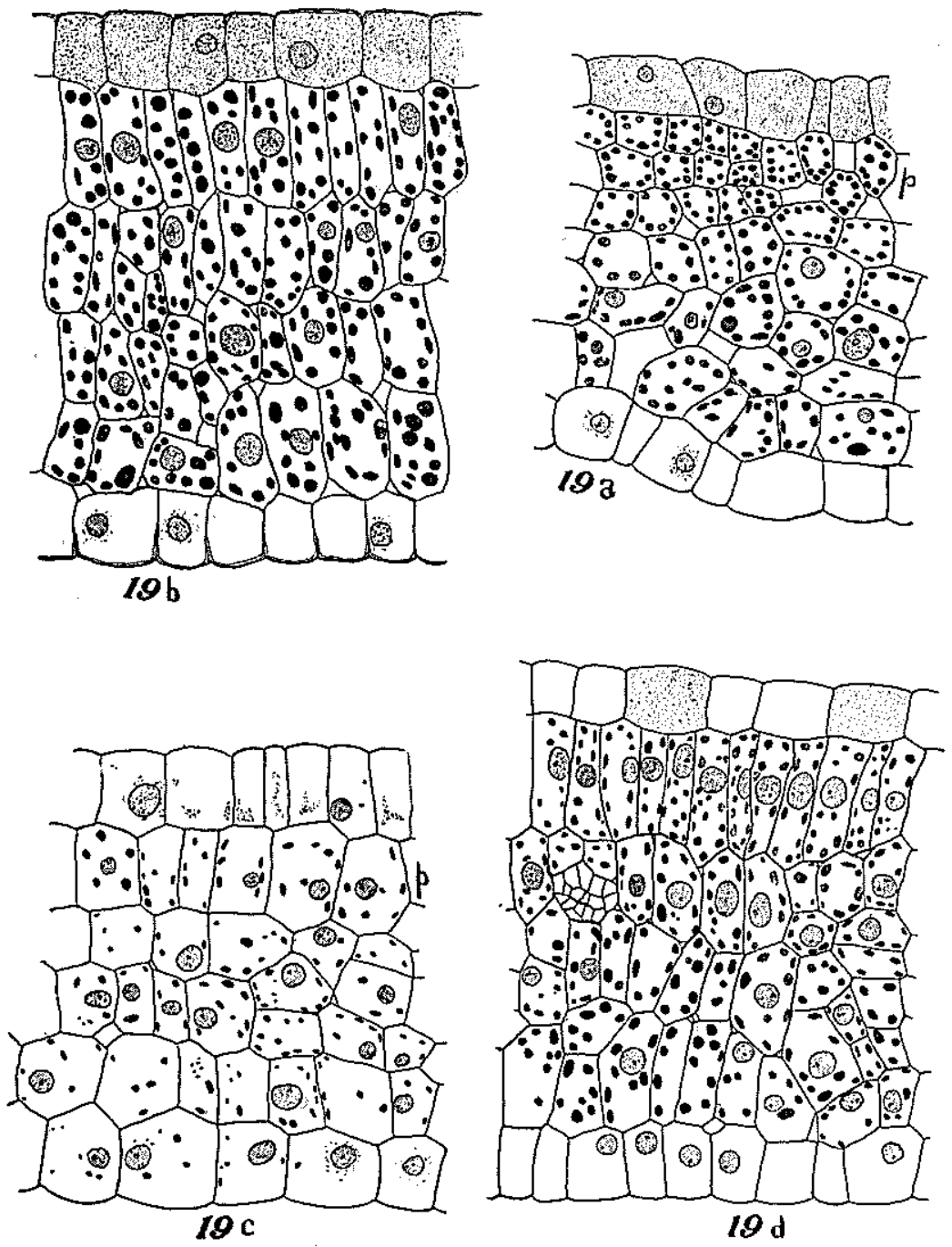


\section{PLATE XIII}
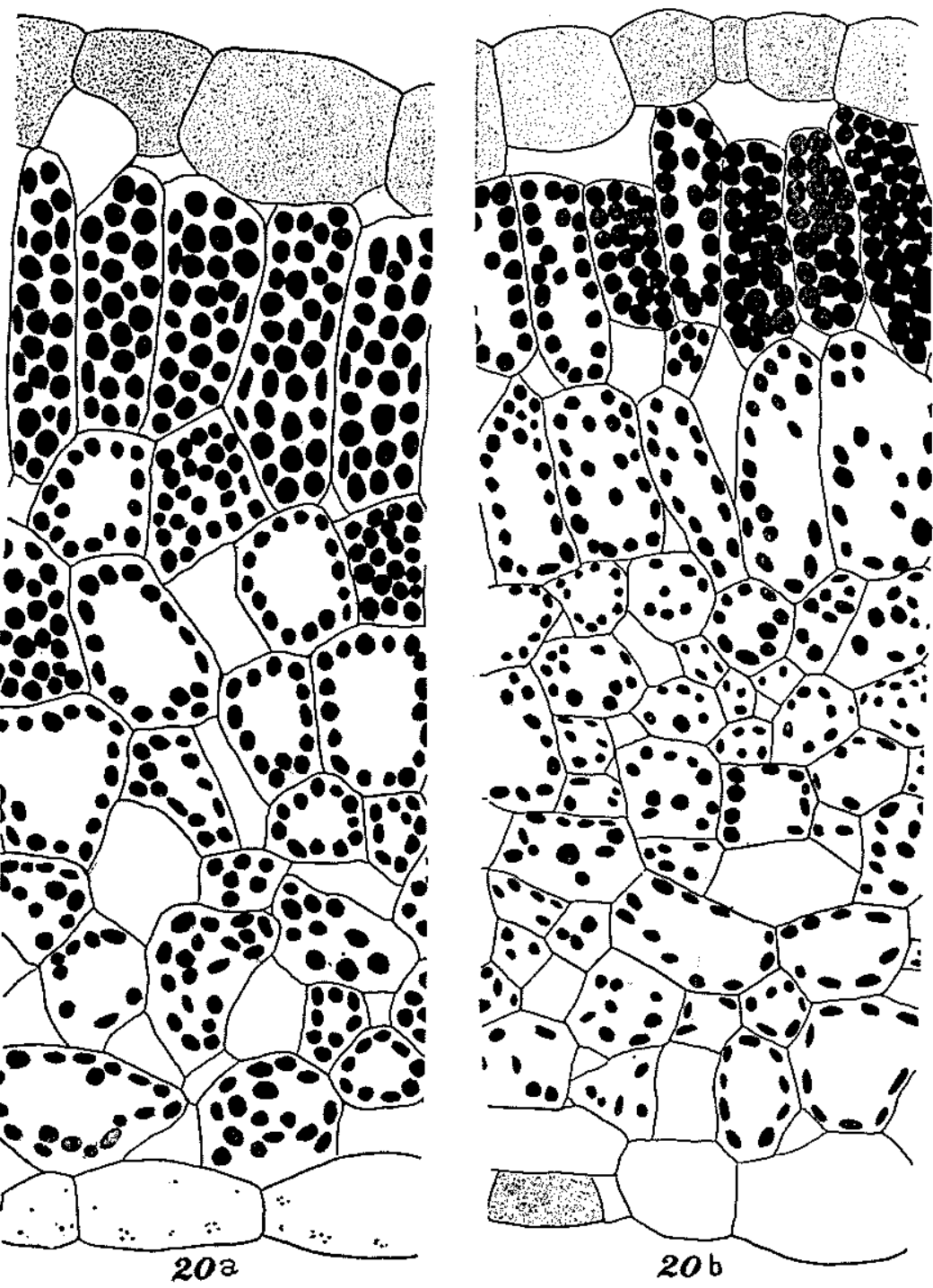
PLATE XIV
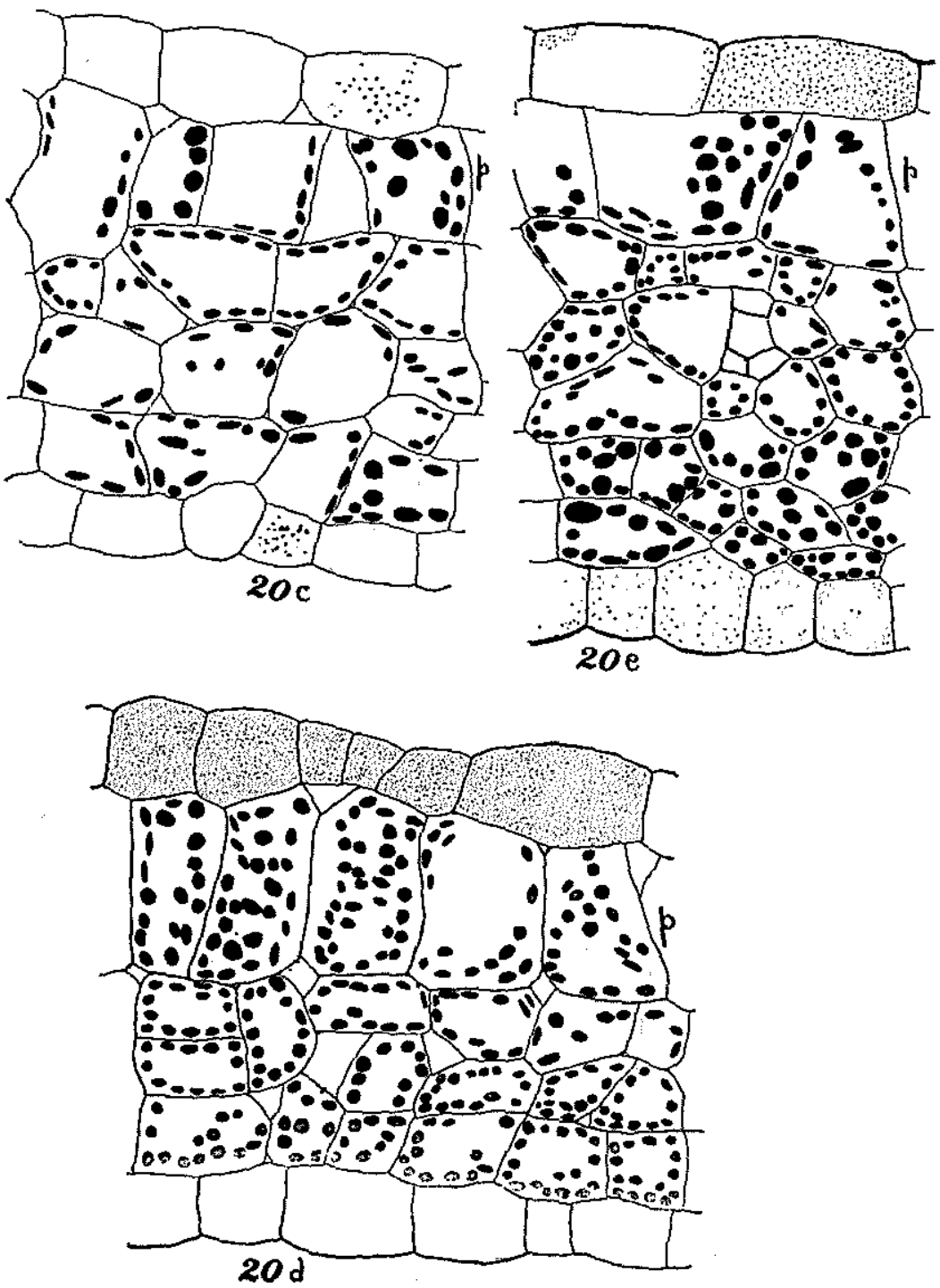